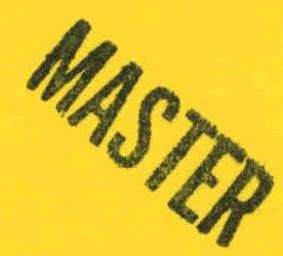

\title{
Development of Reduced-Variable Master Curves for Estimating Tensile Stresses of Encapsulated Solar Cells Caused by Module Deflection or Thermal Expansion
}

\author{
E.F. Cuddihy
}

\section{Prepared for}

U.S. Department of Energy

Through an agreement with

National Aeronautics and Space Administration

by

Jet Propulsion Laboratory

California Institute of Technology

Pasadena, California 


\section{DISCLAIMER}

This report was prepared as an account of work sponsored by an agency of the United States Government. Neither the United States Government nor any agency Thereof, nor any of their employees, makes any warranty, express or implied, or assumes any legal liability or responsibility for the accuracy, completeness, or usefulness of any information, apparatus, product, or process disclosed, or represents that its use would not infringe privately owned rights. Reference herein to any specific commercial product, process, or service by trade name, trademark, manufacturer, or otherwise does not necessarily constitute or imply its endorsement, recommendation, or favoring by the United States Government or any agency thereof. The views and opinions of authors expressed herein do not necessarily state or reflect those of the United States Government or any agency thereof. 


\section{DISCLAIMER}

Portions of this document may be illegible in electronic image products. Images are produced from the best available original document. 


\section{Development of Reduced-Variable Master Curves for Estimating Tensile Stresses of Encapsulated Solar Cells Caused by Module Deflection or Thermal Expansion}

E.F. Cuddihy

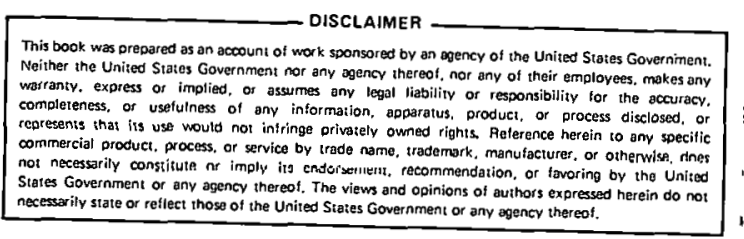

October 1,1981

Prepared for

U.S. Department of Energy

Through an agreement with

National Aeronautics and Space Administration

by

Jet Propulsion Laboratory

California Institute of Technology

Pasadena, California 
Prepared by the Jet Propulsion Laboratory, California Institute of Technology, for the Department of Energy through an agreement with the National Aeronautics and Space Administration.

I he JPL Flat-Plaite 3ula Allay Projest is sponsoped by the Department nf Fnerity (DOE) and forms part of the Photovoltaic Energy Systems Program to initiate a major effort toward the development of cost-competitive sular arrays.

This report was prepared as an account of work sponsored by the United States Government. Neither the United States nor the United States Department of Energy, nor any of their employees, nor any of their contractors, subcontractors, or their employees, makes any warranty, cxpress or implied, or assumes any legal liability or responsibility for the accuracy, completeness or uscfulness of any information, apparatus, product or proccss disclosed, or represents that its uss would not infringe privately owned rights.

Reference lieiein to any specific commercial product, process, or service by trade. name, trademark, inanufacturer, or otherwise, does not necessarily constitute ur imply its endorsement, recommendations, or favoring by the United States Government or any agcncy thereof. The vicws and opinions of authors expressed herein do not necessarily state or reflect those of the United States Government or atiy agency thereof. 


\begin{abstract}
Complex computer programs are being used by Spectrolab, Inc., to achieve encapsulation engineering optimization of photovoltaic modules under Low-Cost Solar Array Project Contract No. 955567. Optimization involves structural adequacy, electrical isolation (safety), maximum optical transmission, and minimum module temperature, at the lowest life-cycle energy cost. A goal of this activity is the generation, where possible, of encapsulation engineering generalities, principles, and design aids (tables or graphs) that would permit a ready, desktop capability of an engineering evaluation of encapsulation options involving materials or designs. This article reports the first efforts to generate reduced-variable master curves to serve as structural-analysis design aids.
\end{abstract}


THIS PAGE

\section{WAS INTENTIONALLY LEFT BLANK}


CONTENTS

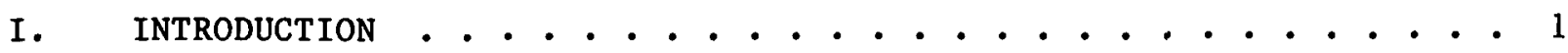

II. STRUCTURAL ANALYSIS PROGRAM . . . . . . . . . . . . . . . 3

III. THERMAL EXPANSION MASTER-CURVE ANALYSIS . . . . . . . . . . . . . 9

A. AlUMINUM PANEL . . . . . . . . . . . . . . . . 13

B. HYGROSCOPIC EXPANSION OF WOOD . . . . . . . . . . 15

IV. DEFLECTION MASTER-CURVE ANALYSIS . . . . . . . . . . . . . . 19

V. FUTURE WORK . . . . . . . . . . . . . . . . . . . 25

REFERENCES . . . . . . . . . . . . . . . . . . . . . 27

\section{Figures}

1. Computer-Predicted Stresses in Encapsulated Silicon Solar Cells Resulting from Thermal Expansion Differences in a Glass-Superstrate Module for a $\Delta \mathrm{T}$ of $100^{\circ} \mathrm{C}$. . . . . . . 5

2. Computer-Predicted Stresses in Encapsulated Silicon Solar Cells Resulting from Thermal Expansion Differences in a Stee1-Substrate Module for a $\Delta \mathrm{T}$ of $100^{\circ} \mathrm{C}$. . . . . . . 5

3. Computer-Predicted Stresses in Encapsulated Silicon Solar Cells Resulting from Thermal Expansion Differences in a Wooden Substrate Module for a $\triangle \mathrm{T}$ of $100^{\circ} \mathrm{C}$. . . . . . . 6

4. Computer-Predicted Stresses in Encapsulated Silicon Solar Cells Resulting from Deflection of a 4-ft Square GlassSubstrate Module under a Uniform Load of $50 \mathrm{lb} / \mathrm{ft}^{2}$. . . . 6

5. Computer-Predicted Stresses in Encapsulated Silicon Solar Cells Resulting from Deflection of 4-ft Square Steel Panels of Threc Different Thicknesses, under a Unitorm Load of $50 \mathrm{Ib} / \mathrm{ft}^{2}$

6. Computer-Predicted Stresses in Encapsulated Silicon Solar Cells Resulting from Deflection under a Uniform Load of $50 \mathrm{lb} / \mathrm{ft}^{2}$ of an Unribbed, 4-ft Square, 1/4-in.-Thick Hardboard, and a Ribbed, 4-ft Square, 1/8-in.-Thick Hardboard 
7. Computer-Predicted Stresses of Encapsulated Silicon Solar Cells Resulting from Thermal Expansion Differences in a Wooden-Substrate Module for a $\Delta \mathrm{T}$ of $100^{\circ} \mathrm{C}$, Using an Artificial Thermal Expansion Coefficient for Wood of

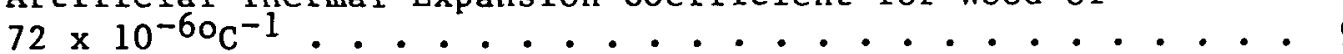

8. Log-Log Plots of Computer Traces Given in Figure 1 for a Glass-Superstrate Design . . . . . . . . . . . 10

9. Log-Log Plot of the Computer Trace Given in Figure 2 for a Steel-Substrate Design . . . . . . . . . . . . 10

10. Horizontally Shifted Computer Traces of Figure 8 for Glass Using Reduced Variable, t/E ............... 11

11. Horizontally Shifted Computer Traces of Figure 7 for Wood

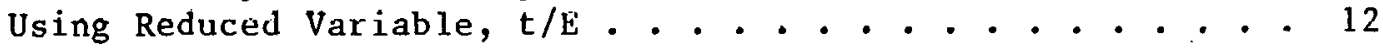

12. Horizontally Shifted Computer Traces of Figures 9, 10, and 11 for Step.1, Glass, and Wood Using the Reduced Variable

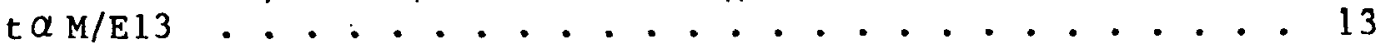

13. Master Curve for Thermal Stress Analysis . . . . . . . . 14

14. Predicted Stresses of Encapsulated Silicon Solar Cells, Using the Figure 13 Master Curve Resulting from ThermalExpansion Differences in an Aluminum Substrate Module for a $\triangle \mathrm{T}$ of $100^{\circ} \mathrm{C}$. . . . . . . . . . . . . . 15

15. Predicted Stresses in Encapsulated Silicon Solar Cells, Using the Figure 13 Master Curve, Resulting from Hygroscopic Expansion of a Hardboard Panel from $0 \%$ to $100 \%$ Relative Humidity . . . . . . . . . . . . . . 16

16. Log-log Plots of the Computer Traces Given in Figure 4 for the Glass-Superstrate Module . . . . . . . . . 19

17. Log-Log Plots of the Computer Traces Given in Figure 5 of a Steel-Substrate Module.............. . 20

18. Log-Log Plot of the Computer Trace Given in Figure 6 for the Unribbed Wood-Substrate Modulc . . . . . . . 20

19. Horizontally Shifted Computer Traces of Figure 16 for Glass Using the Reduced Variable, $t / E$. . . . . . . . . 21

20. Vertically Shifted Computer Traces of Figure 17 for Steel Using the Reduced Variable S/P . . . . . . . . 21

21. Horizontally Shifted Composite Computer Traces of Figures 18, 19, and 20 for Wood, Glass, and Steel to Demonstrate Potential of Superpositon to a Master Curve . . . 22

22. Master Curve for Deflection Stress Analysis . . . . . . . 23 
1. Structural Parameters Used in Phase I Computer Studies for Modules with Unribbed, Flat Structural Panels.

2. General List of Structural Parameters Considered for

Reduced-Variable, Master-Curve Studies 


\section{SECTION I}

\section{INTRODUCTION}

An engineering analysis of encapsulation systems is being made by Spectrolab, Inc., under Low-Cost Solar Array Project (LSA) Contract No. 955567 for the Jet Propulsion Laboratory. 1 The three objectives of the contract are:

(1) Development and verification of general analytical methods and techniques, using material costs and properties as data input, to generate for any combination of materials its optimized module design involving:

(a) Minimum thickness of the structural panel that will satisfy I.SA load requirements

(b) Stressing of solar cells to no higher than allowable stress limits

(c) Minimum material thickness required for electrical isolation safety

(d) Module operating temperature, optical transmission to solar cells, and calculation of module power output

(e) Calculation of life-cycle energy cost.

(2) Identification of the specific combination of materials, and associated module design, yielding the minimum life-cycle energy cost.

(3) Generation, where possible, of encapsulation design generalities, principles, and design guidelines to avoid engineering problems and module failures.

To achieve these three objectives, the technical program has been divided into three phases:

Phase I: (a) Generation of computer programs and analytical models

(b) Establishment of a data base of material properties and costs

(c) Predictions of minimum material requirements and module performance for selected combinations of materials.

\footnotetext{
l Primary support is provided by Hughes Aircraft Corp. under subcontract with
} Spectrolab, Inc. 
Phase II: (a) Experimental validation of predicted module performance

(b) Refinements and modifications of computer programs and analytical models

(c) Identification of a specific combination of materials yielding the minimum life-cycle energy costs.

Phase III: Preparation of design drawings and specifications of an optimized design, suitable for module manufacturers' use.

Phase I, now completed, was computer analysis and simulation modeling, and involved experimental work only for infrequent laboratory measurement of critical material properties, where the needed data did not exist or could not be estimated with the accuracy required for the computer analysis. A Phase I report will be available for general distribution in the fall of 1981. This report focusés only on the computer predictions trom their Phase I structural analysis, and focuses specifically on that feature of the data which permits manipulation into reduced-variable master curves. 
SECTION II

STRUCTURAL ANALYSIS PROGRAM

Phase I structural analysis at Spectrolab consisted of two parts: prediction of stress distribution throughout a 4-ft square module when deflected by a $100-\mathrm{mph}$ wind ( $50 \mathrm{lb} / \mathrm{ft}^{2}$ loading pressure), and prediction of stress distribution throughout a module, set up by thermal stresses when a module is heated through a temperature difference of $100^{\circ} \mathrm{C}$. For both cases, a zero stress-state was assumed to exist throughout the module before deflection or thermal stressing. At present, the two cases have only been separately analyzed; the combined action of wind deflection and thermal stressing has not yet been analyzed.

Details of the module construction that was analyzed are:

(1) Module dimensions: $1.2-\mathrm{m}(4-\mathrm{ft})$ square.

(2) Solar cells: $10 \times 10 \mathrm{~cm}^{2}$ (4 44 in.).

(3) Spacing between solar cells: $1.3 \mathrm{~mm}(0.050 \mathrm{in.})$.

For the deflection analysis, the perimeter of the module was assumed to be constrained and restricted from being twisted or deflected out of planarity. Thus, as the module arcs under a uniform wind pressure load, the edges always remain in the plane of the undeflected, initially flat module.

Deflection and thermal stress analyses were carried out for three encapsulation systems, a glass superstrate, and a wood-and-mild-steel substrate design. The structural properties of the glass, wood, and mild steel were fixed-input data (Table 1). The pottant was treated as a variable, expressed in terms of its Young's modulus. Output data was the stress distribution throughout the module, calculated as a function of the pottant's Young's modulus, and pottant thickness between the cells and the structural panel.

Figures 1 through 6 are the Spectrolab computer plots of solar-cell tensile stresses vs pottant thickness for constant levels of Young's modulus of the pottant. Figures 1,2, and 3 are the computer traces for thermal stressing, and Figures 4, 5, and 6 are the computer traces for deflection. For thermal stressing, the allowable solar cell tensile stress is $50001 \mathrm{~b} / \mathrm{in} .^{2}$, and the allowable solar cell bending stress for deflection is $8000 \mathrm{lb} / \mathrm{in}^{2}$. The rationales for these stress assignments are based partly on earlier work at JPL (Reference 1) measuring the fracture strength of silicon solar cells, and will be discussed in greater detail in the Spectrolab Phase I report.

Whether the tensile stresses in the cells are generated from module deflection or from thermal-expansion differences, the computer-predicted data traces reveal that solar-cell tensile stresses decrease with increasing thickness of the pottant between the cells and the structural panel. The computer results also reveal that increasing the Young's modulus of the pottant requires an increase in the thickness of the pottant to reduce the level of cell 
Table 1. Structural Parameters Used in Phase I Computer Studies for Modules with Unribbed, Flat Structural Panels

\begin{tabular}{|c|c|c|c|}
\hline & \multirow{2}{*}{$\begin{array}{l}\text { Parameter } \\
\text { Young's modulus (Modulus) } \\
\text { Thickness } \\
\text { Thermal-expansion coefficient }\end{array}$} & \multirow{2}{*}{$\begin{array}{l}\text { Input Status } \\
\text { Variable } \\
\text { Variable } \\
\text { Fixed }\end{array}$} & \multirow{2}{*}{$\begin{array}{l}\text { Values } \\
0.5 \text { to } 250\left(10^{3} / \mathrm{in}^{2}\right) \\
1 \text { to } 16 \mathrm{mils} \\
10^{-4} \text { in. } /\left(\mathrm{in} .{ }^{\circ} \mathrm{C}\right)\end{array}$} \\
\hline Component & & & \\
\hline Solar cell & $\begin{array}{l}\text { Modulus } \\
\text { Thickness } \\
\text { Length and width } \\
\text { Thcrmal-cupanoion cocffioicnt } \\
\text { Intercell spacing }\end{array}$ & $\begin{array}{l}\text { Fixed } \\
\text { Fixed } \\
\text { Fixed } \\
\text { Fixed } \\
\text { Fixed }\end{array}$ & $\begin{array}{l}17 \times 10^{6} 1 \mathrm{~b} / \mathrm{in} .^{2} \\
15 \mathrm{mils} \\
\text { Square ce } 11 ; 10 \mathrm{~cm} \text { on } \\
\text { a side } \\
1.4 \times 10^{-6} \mathrm{in.} /\left(\mathrm{in} .-{ }^{\circ} \mathrm{C}\right) \\
1.3 \mathrm{~mm}\end{array}$ \\
\hline Glass & $\begin{array}{l}\text { Modulus } \\
\text { Thickness } \\
\text { Area } \\
\text { Thermal-expansion coefficient }\end{array}$ & $\begin{array}{l}\text { Fixed } \\
\text { Fixed } \\
\text { Fixed } \\
\text { Fixed }\end{array}$ & $\begin{array}{l}10 \times 10^{6} \mathrm{lb} / \mathrm{in.} .^{2} \\
125 \mathrm{mils} \\
4-\mathrm{ft} \text { square } \\
9.2 \times 10^{-6} \mathrm{in} . / \\
\left(\text { in. }-{ }^{\circ} \mathrm{C}\right)\end{array}$ \\
\hline Steel 1 & $\begin{array}{l}\text { Modulus } \\
\text { Thickness } \\
\text { Area } \\
\text { Therma1-expansion coefficient }\end{array}$ & $\begin{array}{l}\text { Fixed } \\
\text { Variable } \\
\text { Fixed } \\
\text { Fixed }\end{array}$ & $\begin{array}{l}30 \times 10^{6} \mathrm{lb} / \mathrm{in} .^{2} \\
28,87 \text {, and } 168 \mathrm{mils} \\
4-\mathrm{ft} \text { square } \\
10.8 \times 10^{-6} \mathrm{in.} / \\
\left(\mathrm{in} .{ }^{\circ} \mathrm{C}\right)\end{array}$ \\
\hline Wood & $\begin{array}{l}\text { Modulus } \\
\text { Thickness } \\
\text { Area } \\
\text { Thermal-expansion coefficient }\end{array}$ & $\begin{array}{l}\text { Fixed } \\
\text { Fixed } \\
\text { Fixed } \\
\text { Variable }\end{array}$ & 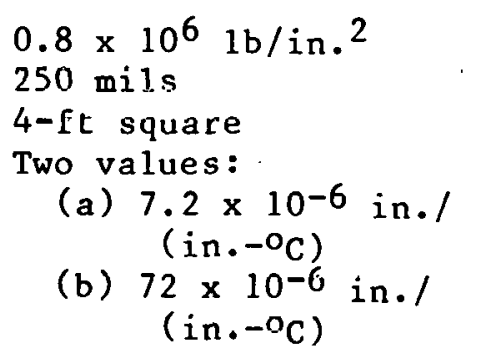 \\
\hline
\end{tabular}

tensile stresses. The structural-analysis computer program identified the Young's modulus and thickness of pottants as key structural properties involved in regulating the level of stresses developed in solar cells.

Therefore, these computer-predicted traces can be considered to deal with that situation where the structural panel is a generator of stress, resulting from either deflection or thermal-expansion differences and the pottant acts to damp the transmission of the generated stress to the solar cells. The computer findings indicate that the efficiency of a pottant in damping stress transmission increases with increasing pottant thickness and with decreasing pottant modulus. But computer findings do not immediately provide comparable information for the panels, as they do for the pottants. Stress generation by a 


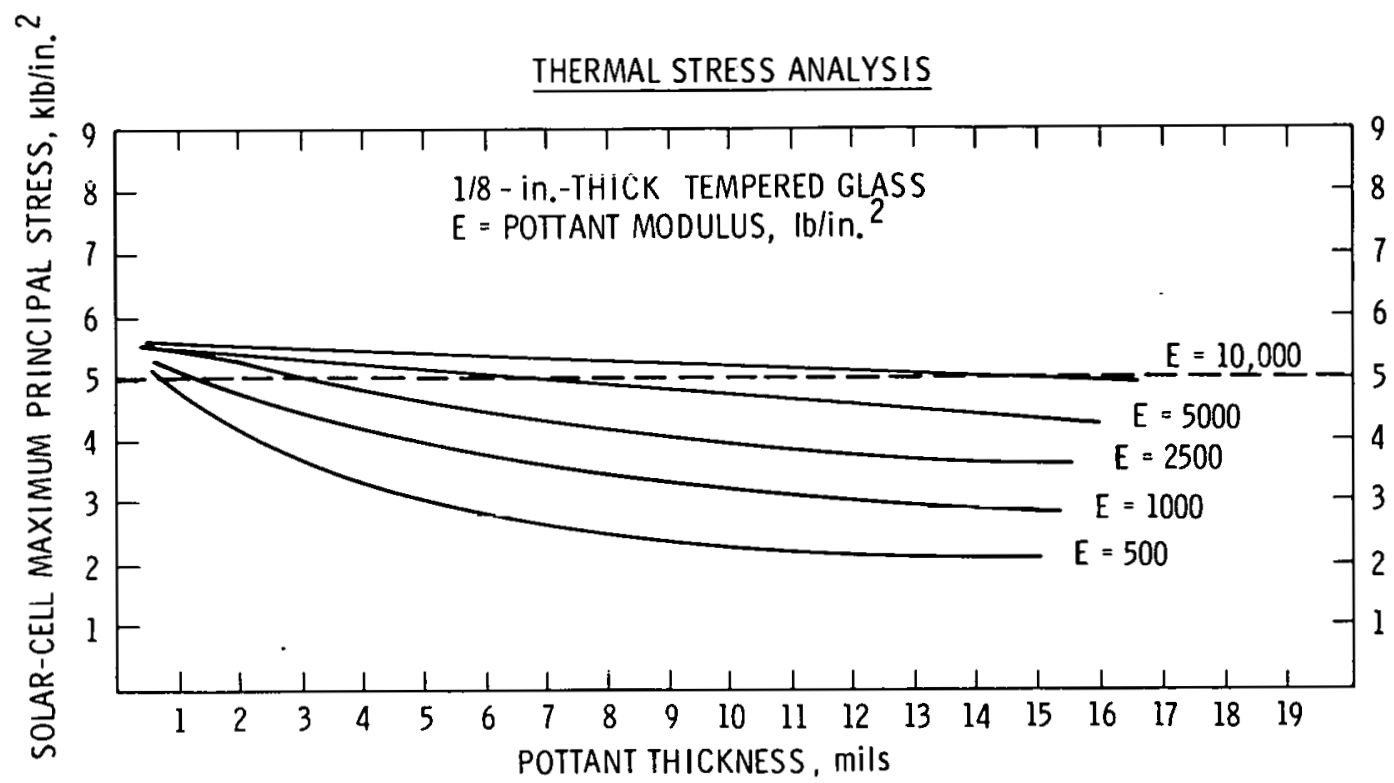

DOTTED LINE = ALLOWABLE CELL STRESS IN TENSION

Figure 1. Computer-Predicted Stresses in Encapsulated Silicon Solar Cells Resulting from Thermal Expansion Differences in a GlassSuperstrate Module for a $\triangle \mathrm{T}$ of $100^{\circ} \mathrm{C}$

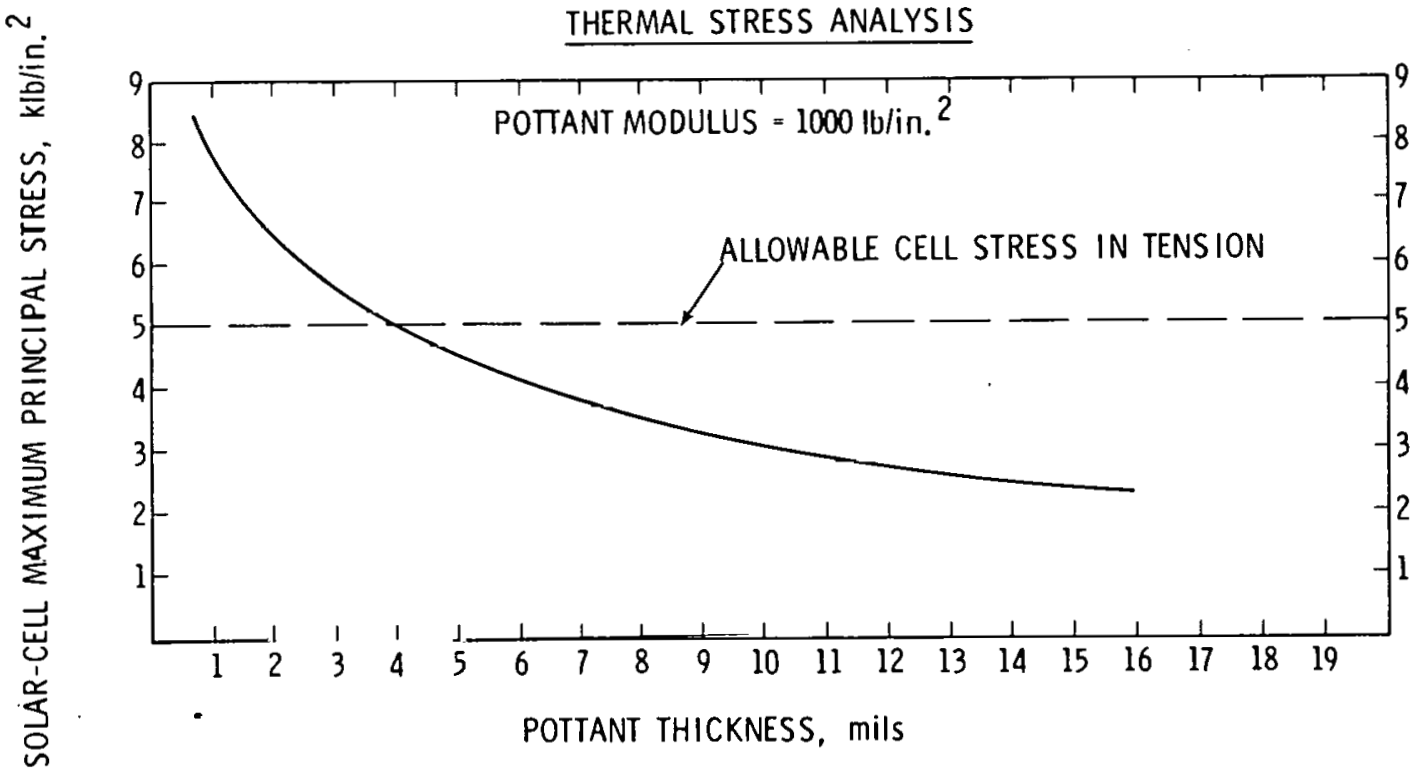

Figure 2. Computer-Predicted stresses in Encapsulated Silicon Solar Cells Resulting from Thermal Expansiun Differences in a steel-substrate Module for a $\Delta \mathrm{T}$ of $100^{\circ} \mathrm{C}$ 


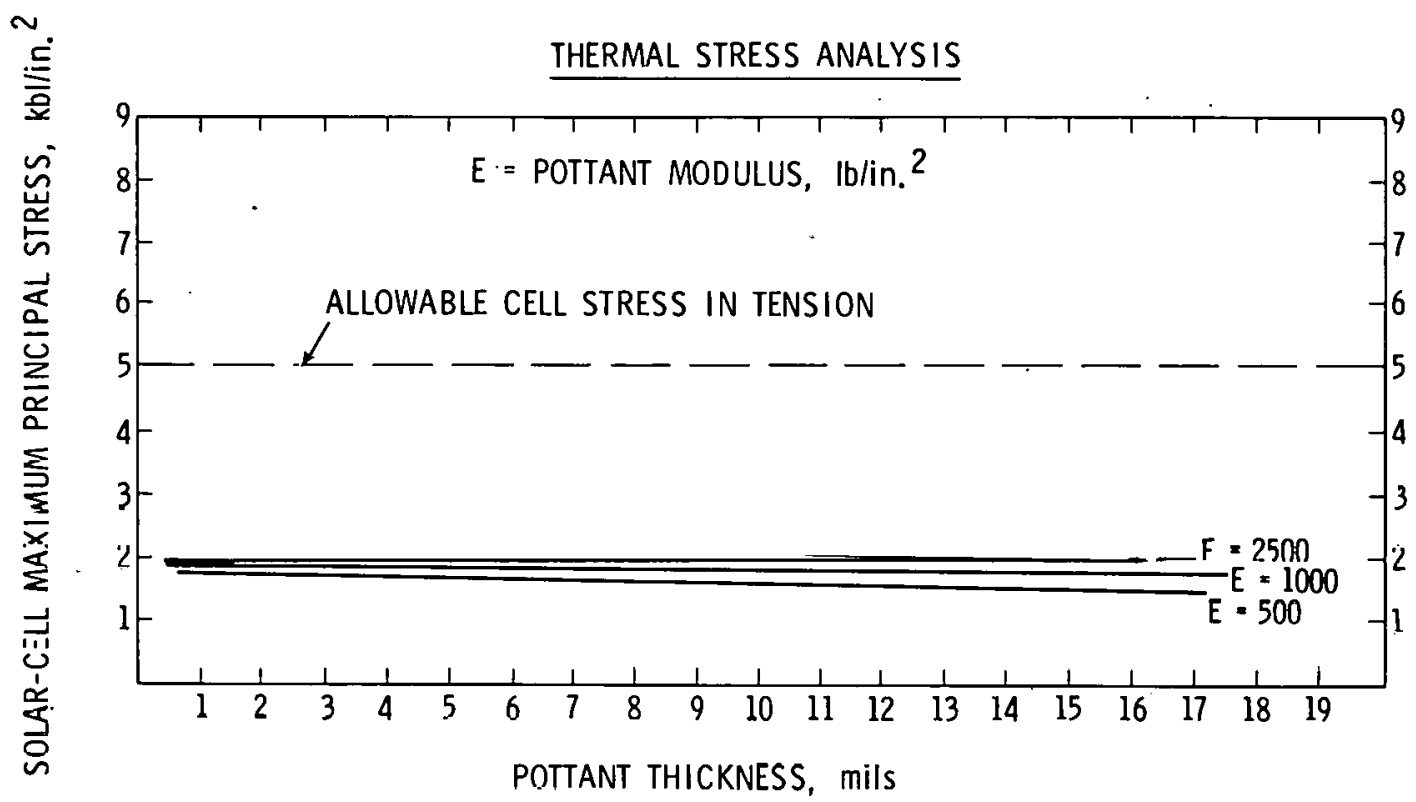

Figure 3. Computer-Predicted Stresses in Encapsulated Silicon Solar Cells Resulting from Thermal Expansion Differences in a Wooden Substrate Module for a $\Delta \mathrm{T}$ of $100^{\circ} \mathrm{C}$

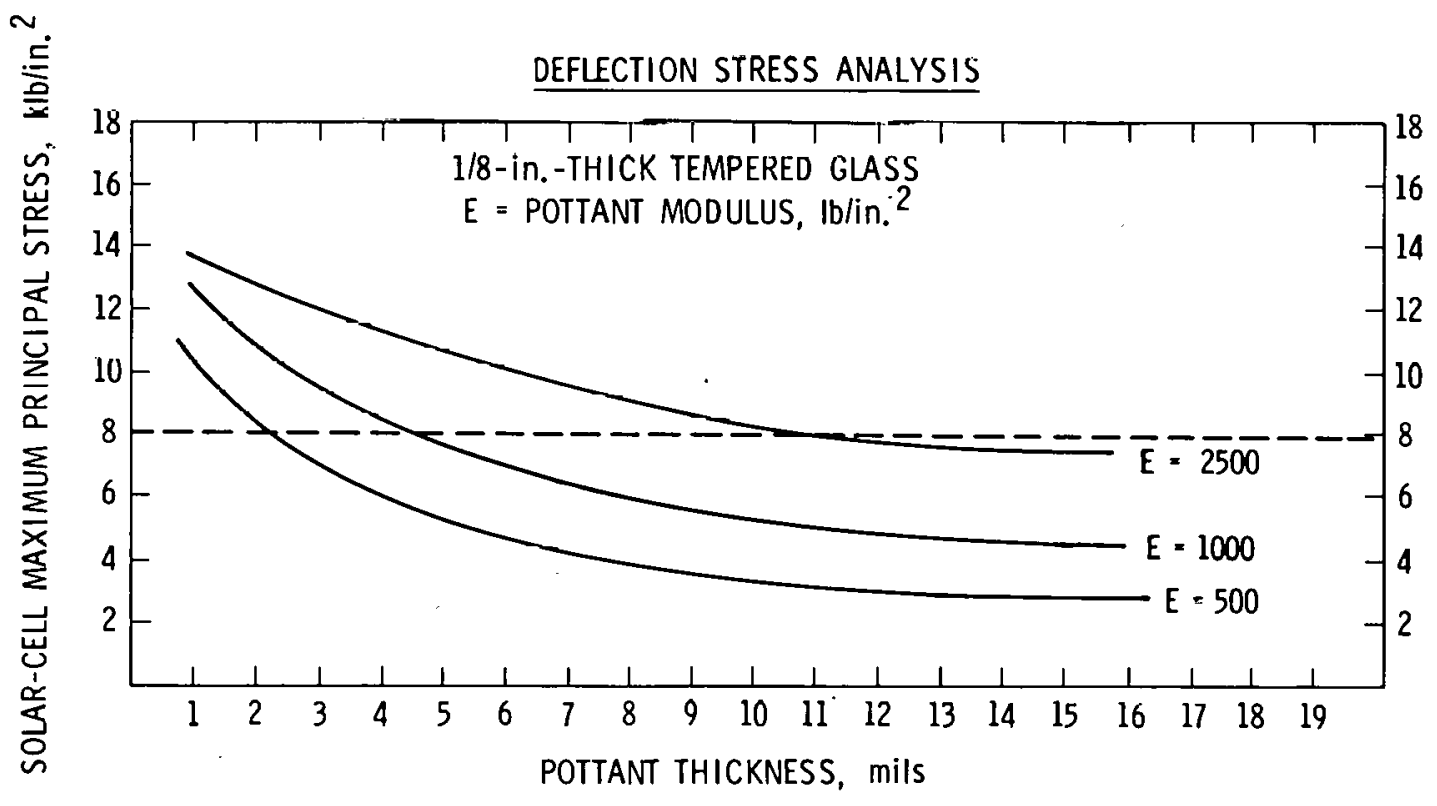

DOTTED LINE = ALLOWABLE CELL STRESS IN DEFLECTION

Figure 4. Computer-Predicted Stresses in Encapsulated Silicon Solar Cells Resulting from Deflection of a 4-ft Square Class-Substrate Module under a Uniform Load of $50 \mathrm{lb} / \mathrm{ft}^{2}$ 
DEFLECTION STRESS ANALYSIS

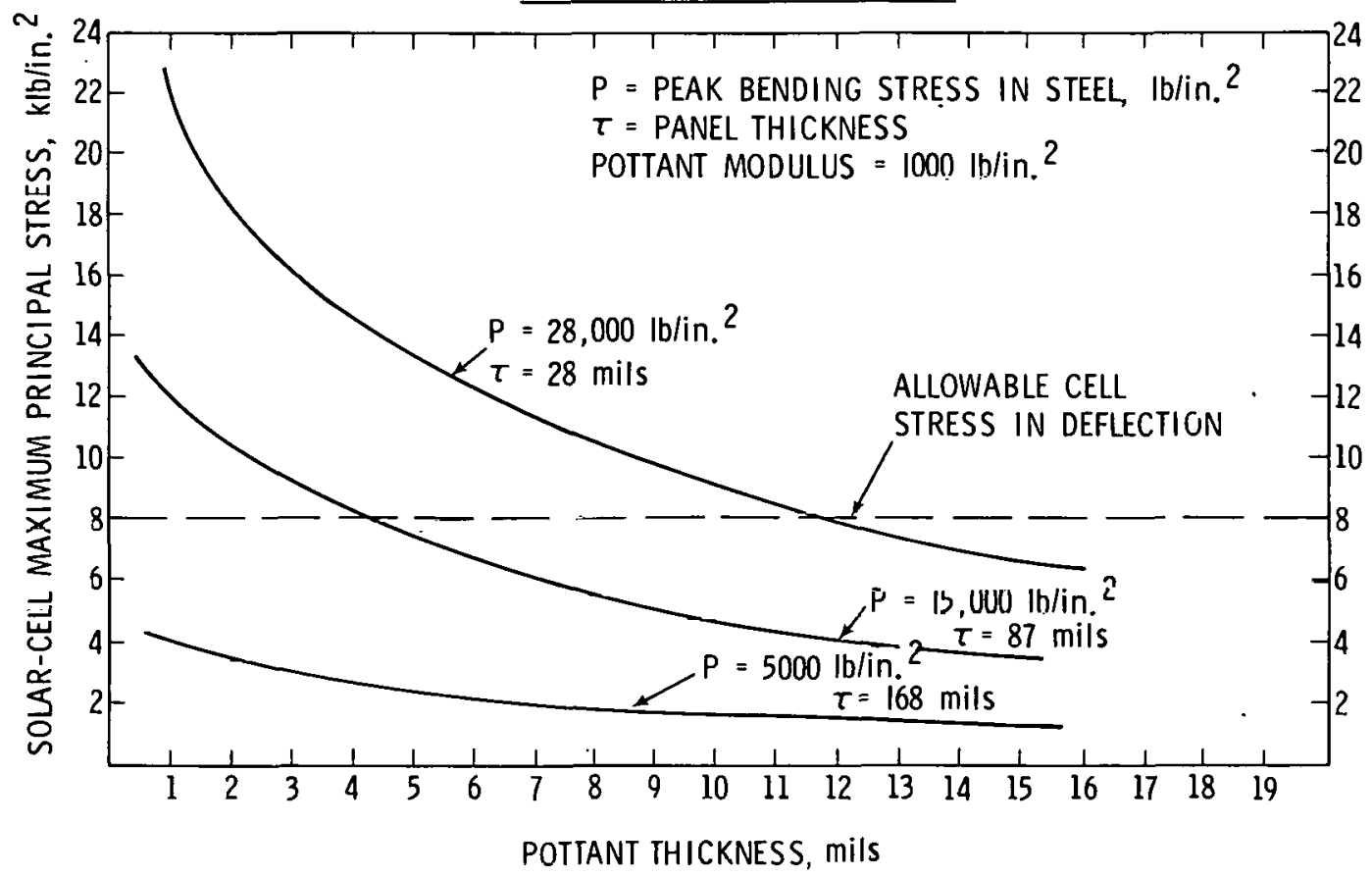

Figure 5. Computer-Predicted Stresses in Encapsulated Silicon Solar Cells Resulting from Deflection of 4-ft Square Steel Panels of Three Different Thicknesses, under a Uniform Load of $50 \mathrm{lb} / \mathrm{ft}^{2}$

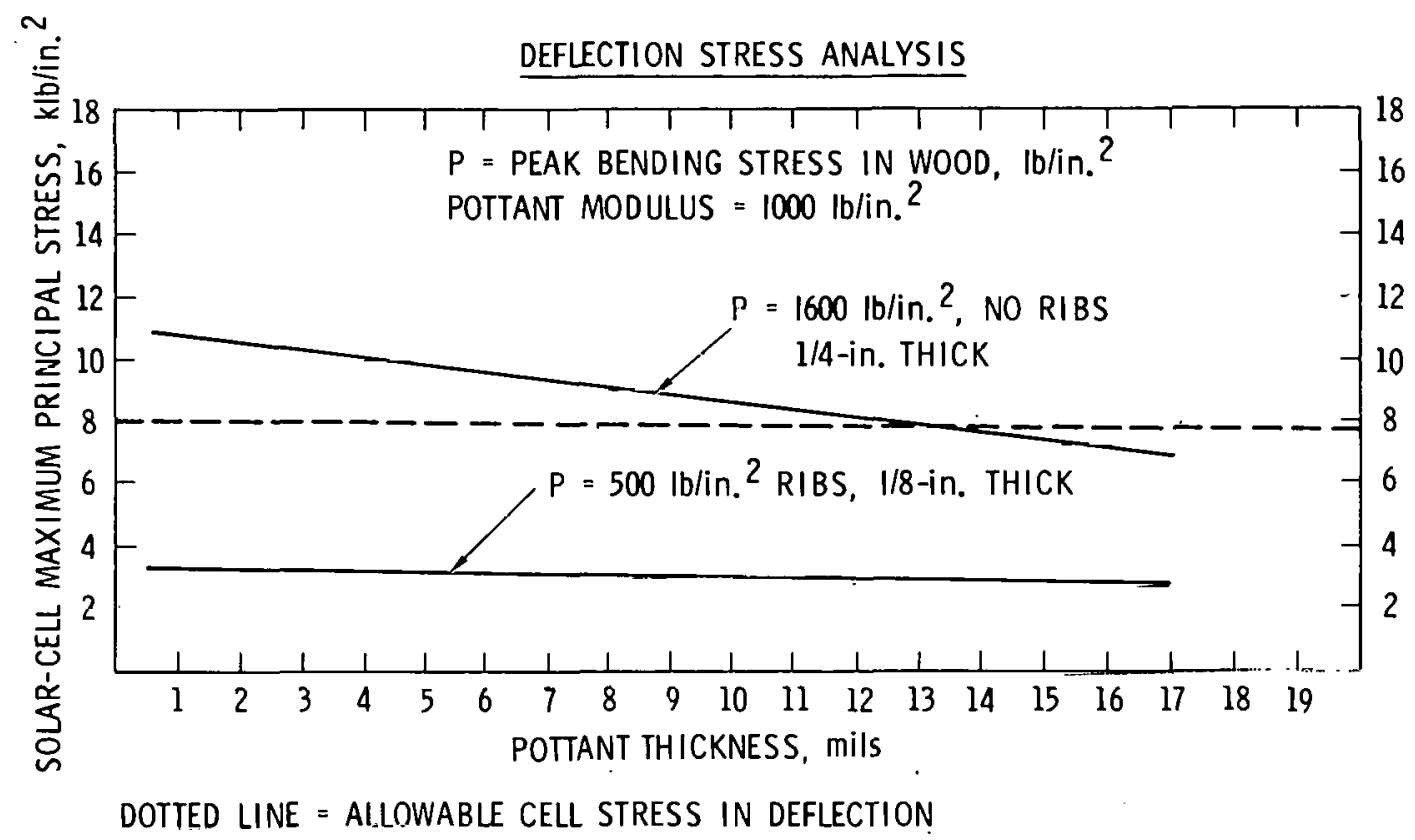

Figure 6. Computer-Predicted Stresses in Encapsulated Silicon Solar Cells Resulting from Deflection under a Uniform Load of $50 \mathrm{lb} / \mathrm{ft}^{2}$ of an Unribbed, 4-ft Square, 1/4-in. -Thick Hardboard, and a Ribbed, 4-ft Square, 1/8-in.-Thick Hardboard 
structural panel can be expected to involve panel properties, such as Young's modulus, thermal expansion, thickness and area, and loading conditions, such as the magnitude of the wind loads and temperature excursions. But inspection of Figures 1 to 6 does not readily reveal for panels the trends or directions that would enable a general assessment or estimate for panels other than glass, wood, or steel. Also, primarily due to computer cost, running time, and demands on the computer for other Phase I calculations, several of the structural computer runs involved analysis for only a single Young's modulus of a pottant. This yields upper-bound information for pottants having a lower Young's modulus, but is not much help in assessing pottants having higher values of Young's modulus.

Generation of computer traces for any combination or choice of pottant and panel is impractical, not only due to cost, but also, and more importantly, due to the necessity of maintaining in readiness the computer capability whenever the information is desired, or whenever new pottants or panel candidates are identified in the future. An effort was made to determine if the structural computer traces plotted in Figures 1 through 6 could be used to genterate com.". posite, reduced-variable master curves that would provide a desktop capability of estimating or approximating solar cell tensile stresses from any combination or choice of pottants and panels. The effort to develop master curves for both thermal expansion and wind deflection, using the structural computer traces generated from the Phase I analytical activities, is described in Sections III and IV. 
To facilitate generation of a reduced-variable master curve, it is necessary to replot the computer traces for thermal stressing (Figures 1, 2, and 3) on log-log graph paper. A trial operation involving horizontal and vertical shifting of the log-log data traces revealed that a composite master curve could be pieced together. The log-log computer traces for wood generated from Figure 3, however, were of no help because these traces were essentially parallel with the abscissa. Spectrolab was asked to generate log-log data traces for a wooden-panel module, using an artificial thermal-expansion value 10 times higher than actual, i.e., $7.2 * 10^{-50} \mathrm{C}^{-1}$ as compared to the actual value of $7.2 * 10^{-60} \mathrm{C}^{-1}$. Log- $\log$ computer traces for wood with this artificial expansion value, and for two levels of Young's modulus for the pottant, 1000 and $5000 \mathrm{lb} / \mathrm{in}^{2}$, are plotted in Figure 7. The use of the artificial expansion coefficient develops curvature in the computer traces, which better aids the horizontal and vertical positioning of these traces into the composite master curve. The computer traces for glass and steel (Figures 1 and 2), replotted $\log -\log$, are shown in Figures 8 and 9 , respectively. Given the observation that all of the $\log -\log$ traces in Figures 7,8 , and 9 could be shifted into a master curve, the remaining activity was to identify reducedvariable expressions for the ordinate and abscissa, which would achieve mathematical merging all of the segments into the composite master curve.

DEFLECTION STRESS ANALYSIS

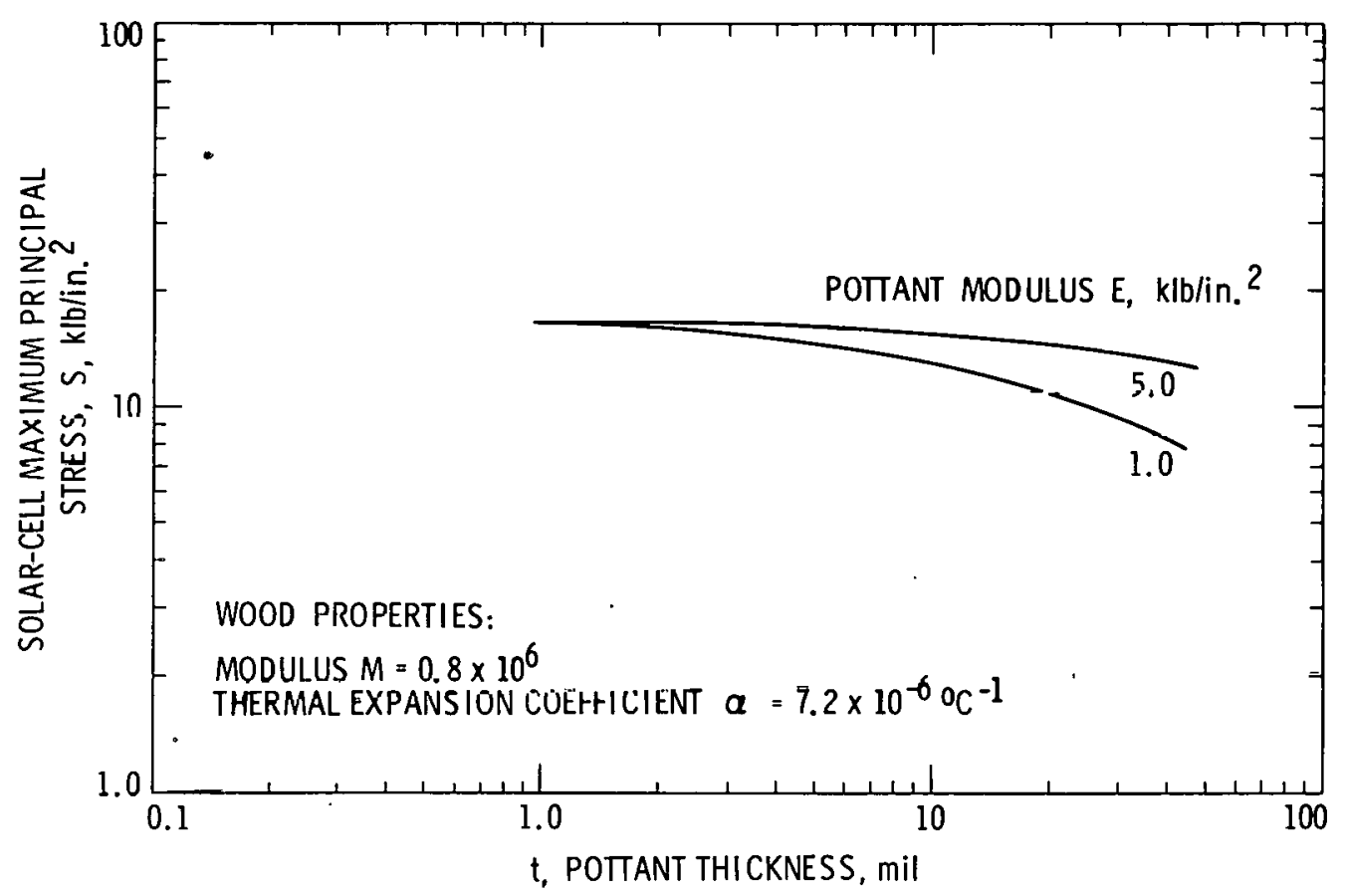

Figure 7. Computer-Predicted Stresses of Encapsulated Silicon Solar Cells Resulting from Thermal Expansion Differences in a WoodenSubstrate Module for a $\Delta \mathrm{T}$ of $100^{\circ} \mathrm{C}$, Using an Artificial Thermal Expansion Coefficient for Wood of $72 \times 10^{-60} \mathrm{C}^{-1}$ 
THERMAL STRESS ANALYSIS

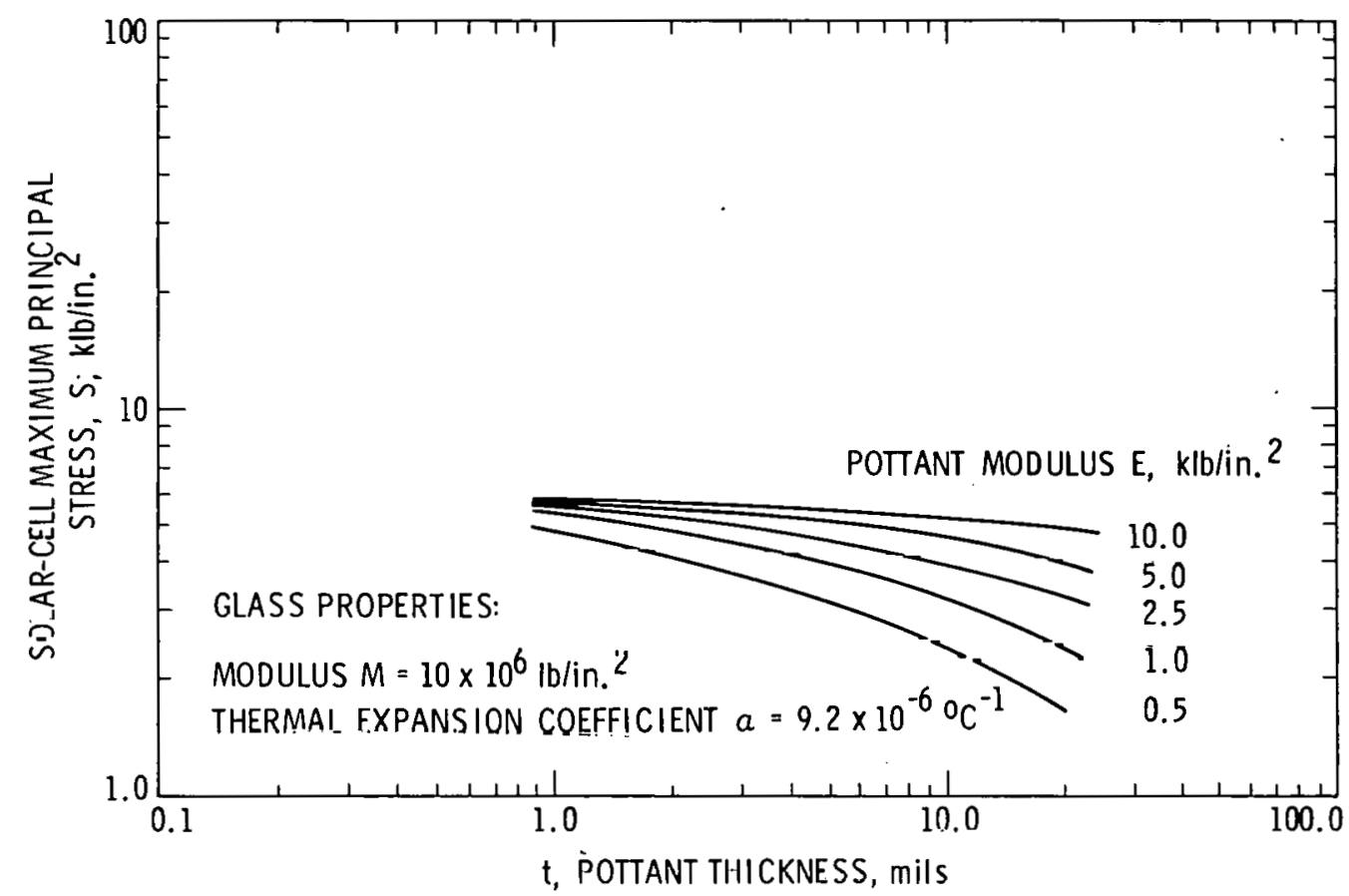

Figure 8. Log-Log Plots of Computer Traces Given in Figure 1 for a Glass-Superstrate Design

\section{THERMAL STRESS ANALYSIS}

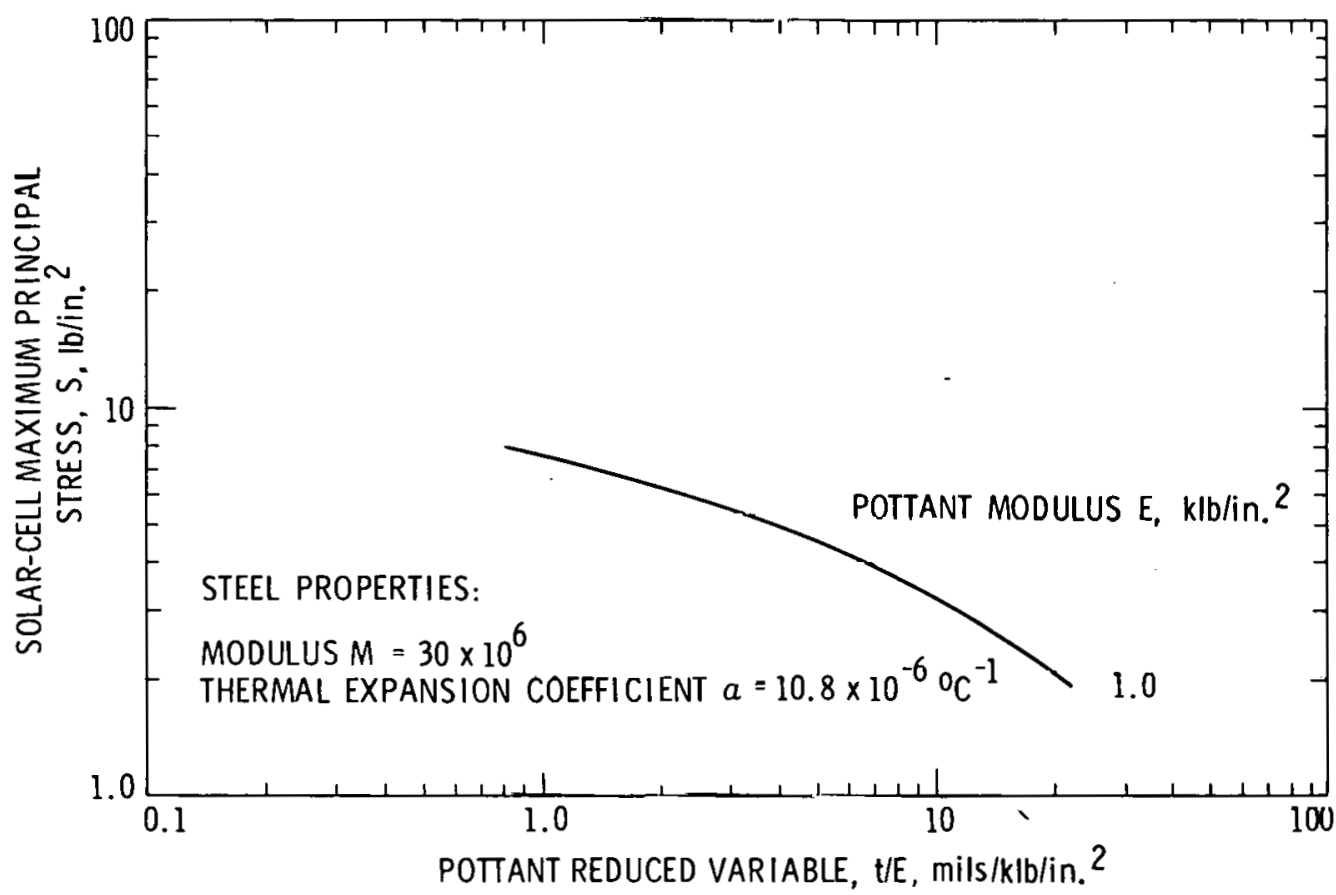

Figure 9. Log-Log Plot of the Computer Trace Given in Figure 2 for a Steel-Substrate Design 
To begin developing the master curve, the log-log traces for glass (Figure 8) can be horizontally shifted to a composite curve (Figure 10), and from the relative magnitudes of the shift ratios, a reduced abscissa variable, $t / E$, is generated. The terms in the variable are $t$, thickness of the pottant in mils, and E, Young's modulus of the pottant in units of $\mathrm{klb} / \mathrm{in} .{ }^{2}$. Accepting $t / E$ as a valid reduced variable for the abscissa, the two computer traces for wood that were calculated with the artificial thermal-expansion coefficient (Figure 7), were appropriately shifted horizontally. The shifted plots are shown in Figure 11, where the two traces for $E=1000$ and $50001 \mathrm{~b} / \mathrm{in} .^{2}$ merge into a composite curve.

For steel (Figure 9), the single computer trace for $E$ is $1 \mathrm{k} 1 \mathrm{~b} / \mathrm{in} .^{2}$. Accepting $t / E$ as valid, this computer trace is properly positioned along the horizontal axis for the reduced variable $t / E$.

The composite curves for steel, glass, and wood (plotted with the reduced absicssa variable $t / E$, Figures 9,10 , and 11 , respectively) are still apart both horizontally and vertically. Trial shifting of these composite curves reveals that they are still three segments of a common master curve. In earlier work at JPL (References 2 and 3 ) using computer techniques to predict stress distributions throughout modules that are generated by thermal-expansion differences, thermal stiffness was observed to be a variable in the computer programs. For any given material, the thermal stiffness is the product of Young's modulus and thermal-expansion coefficient. As a trial term for the reduced-variable scheme, the thermal stiffness of each of the three structural panels (glass, wood, and steel) was calculated, with the product term expressed as $M \alpha$, where $M$ is the Young's modulus of the structural panel, and $\alpha$ is its corresponding expansion coefficient.

\section{THERMAL STRESS ANALYSIS}

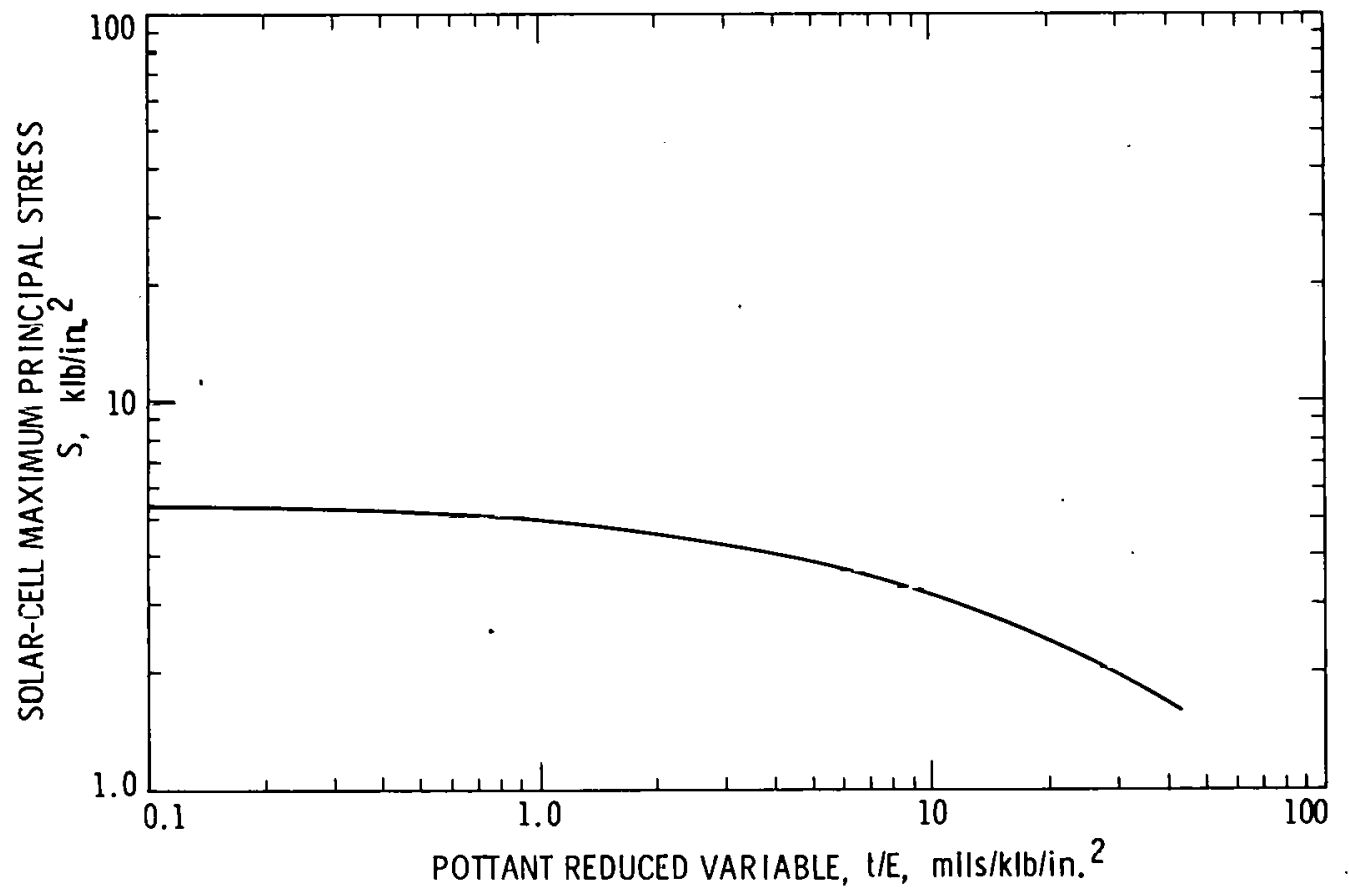

Figure 10. Horizontally Shifted Computer Traces of Figure 8 for Glass Using Reduced Variable, $t / E$ 


\section{THERMAL STRESS ANALYSIS}

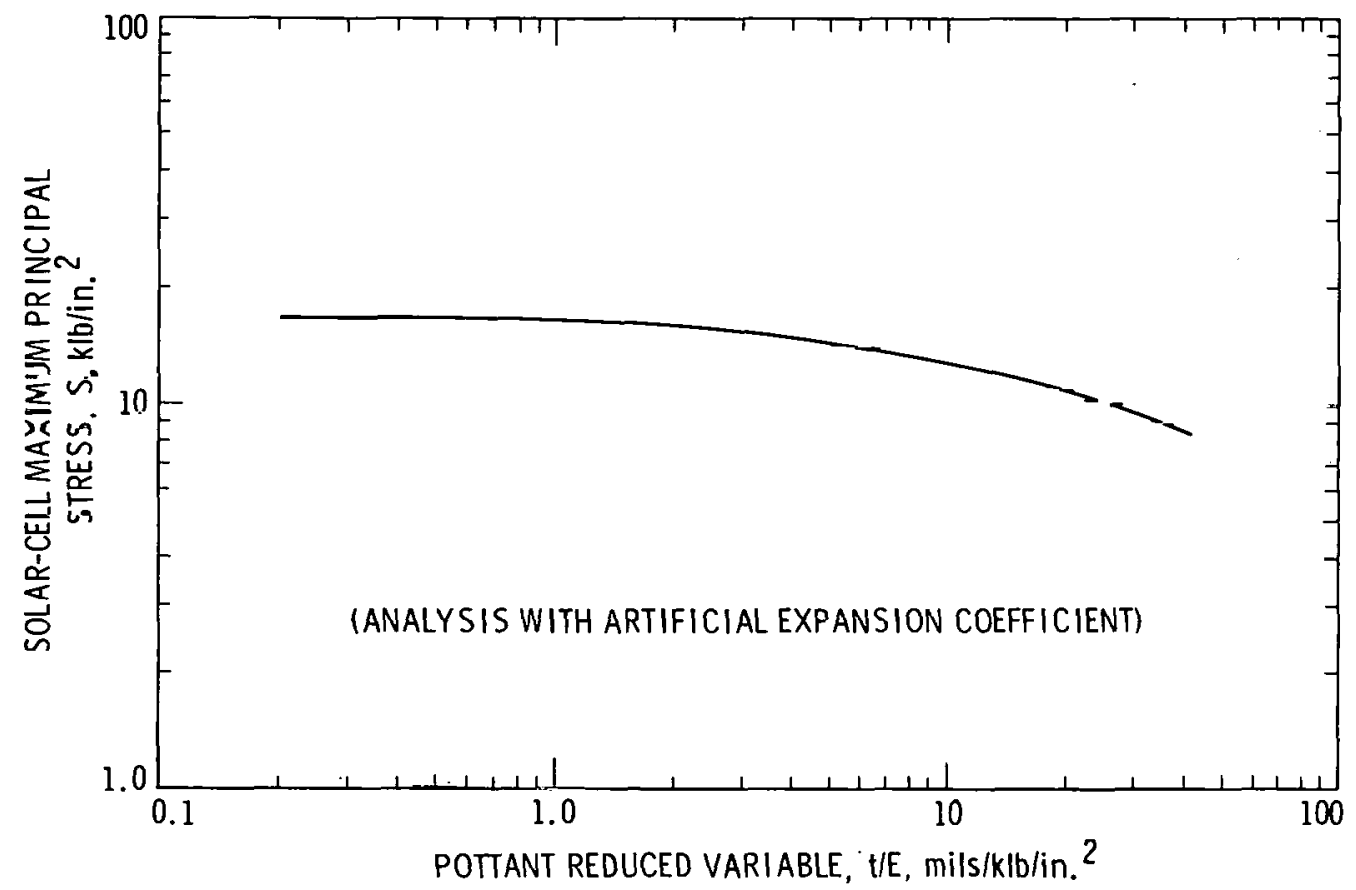

Figure 11. Horizontally Shifted Computer Traces of Figure 7 for Wood Using Reduced Variable, $t / E$

Using the thermal-stiffness values, four trial reduced-parameter terms were calculated, two for the ordinate and two for the abscissa: $s \alpha M, s / \alpha M$, $t \alpha M / E$, and $t / \alpha M E$. The best fit occurred with the third term, $t \alpha M / E$, which resulted in a horizontal shifting of the three composite curves (Figures 9, 10 , and 11 ), requiring only vertical alignment as shown in Figure 12 .

Finally, to merge these three curves vertically into a common master curve, it was noted when comparing the two computer calculations carried out for the wooden panel (Figures 3 and 7 ), that the asymptotic levels of the solar-cell tensile stress $S$ were essentially different by a factor of 10 . Since the only difference between these two calculations for the wooden panel involved the use of expansion coefficients $\alpha$ which differed by a factor of 10 , it was reasoned that the reduced-variable term for the ordinate involved at least the form $\mathrm{S} / \alpha$. Use of this reduced ordinate variable helped, but did not completely achieve the desired vertical merging of the three curves. Thereafter, the effort involved trial-and-error combinations of parameters, finally resulting in identification of the term, $S / \alpha M^{1 / 3}$, which did achieve a vertical merging of the three curves into a common master curve. 


\section{THERMAL STRESS ANALYSIS}

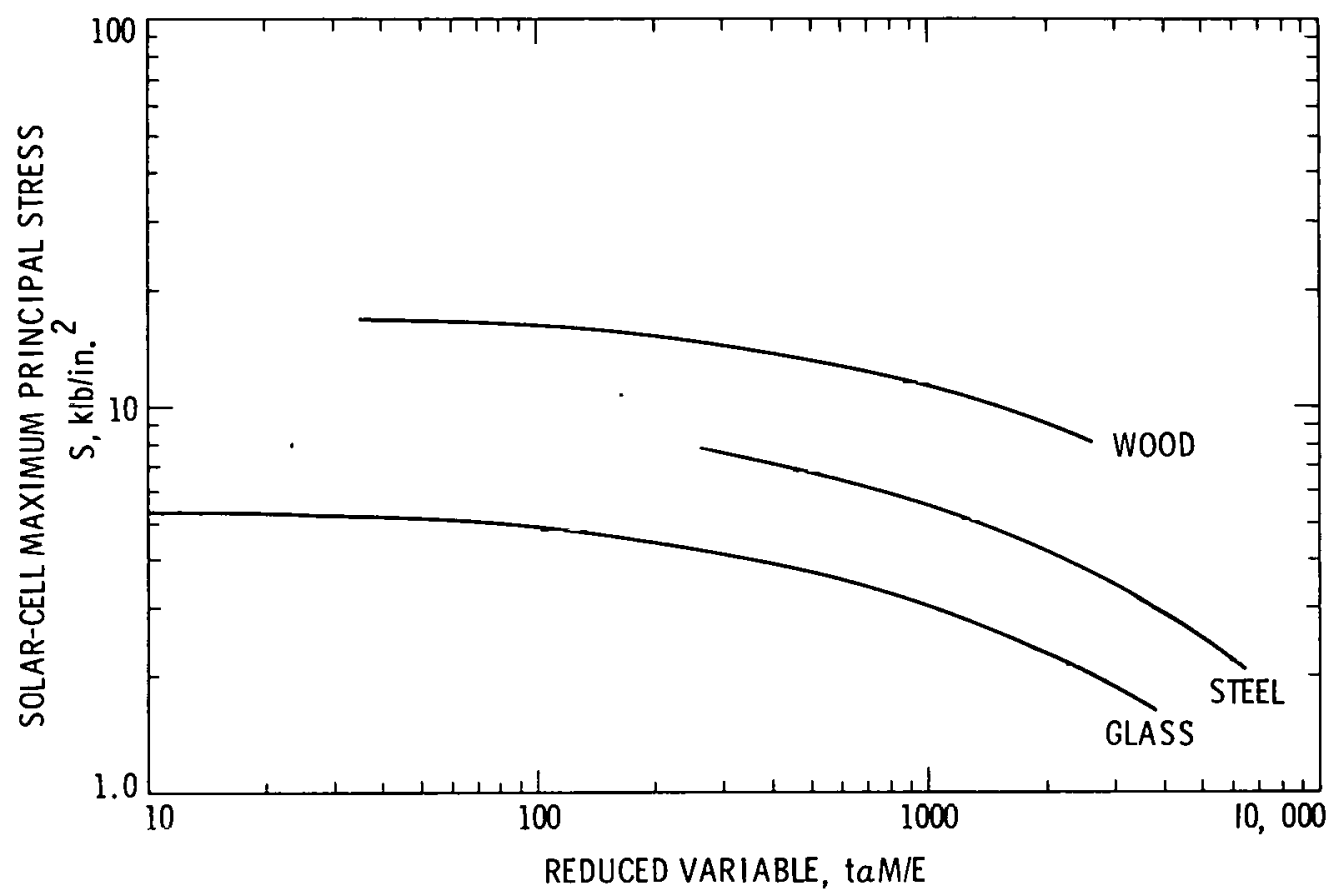

Figure 12. Horizontally Shifted Computer Traces of Figures 9, 10, and 11 for Steel, Glass, and Wood Using the Reduced Variable taM/E

The computer program also indicates that the level of the solar-cell tensile stress $\mathrm{S}$ is directly proportional to the temperature difference, $\Delta \mathrm{T}$. Thus, the reduced ordinate variable can be expressed as $\mathrm{S} / \alpha \mathrm{M}^{1 / 3} \Delta \mathrm{T}$. The resulting master curve, plotted with the reduced variables, $s / \alpha \mathrm{M}^{1} / 3 \Delta \mathrm{T}$, vs $\mathrm{t} \alpha \mathrm{M} / \mathrm{E}$, is given in Figure 13. Although all of the computer-predicted $\log -\log$ traces are seen to be segments of this composite master curve, the validity of the reduced parameters has not been verified.

If valid, the master curve can be used to estimate solar-cell tensile stresses for aluminum panels and the hygroscopic expansion of wood.

\section{A. ALUMINUM PANEL}

The Young's modulus $M$ for aluminum is $10 \times 10^{6} 1 \mathrm{~b} / \mathrm{in} .^{2}$, and its expansion coefficient $\alpha$ is $24 \times 10^{-6}{ }^{\circ} \mathrm{C}^{-1}$. Using these values, $10 \mathrm{~g}-1 \mathrm{og}$ traces of solar-cell tensile stress $S$ vs pottant thickness $t$ can be generated from the master curve for $\Delta \mathrm{T}=100^{\circ} \mathrm{C}$. The resulting $\log -1 \mathrm{log}$ traces for four levels of the Young's modulus of the pottant, $E=500,1000,2000$, and $5000 \mathrm{lb} / \mathrm{in.} .^{2}$, are given in Figure 14. 


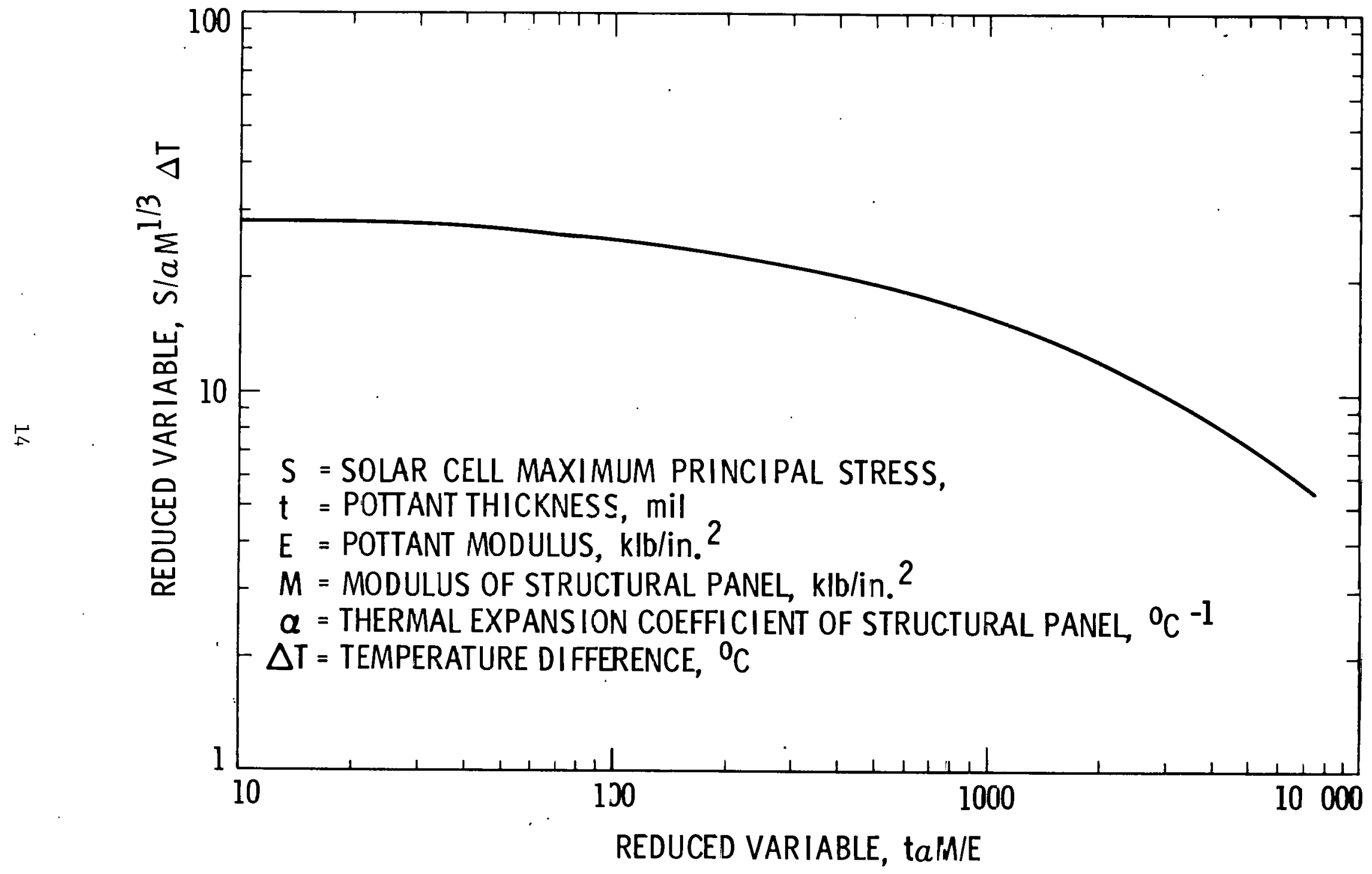

Figure 13. Master Curve for Thermal Stress Aralysis 
Examination of these predicted $\log -\log$ traces indicates that aluminum is worse than glass, wood, or steel in its tendency to generate tensile stresses in solar cells from thermal-expansion differences. This is expected, due to the high thermal-expansion value for aluminum. Accepting that the allowable solar-cell tensile stress in tension is $5000 \mathrm{lb} / \mathrm{in} .{ }^{2}$, it is predicted that almost 7 mils or more of a pottant having a Young's modulus of $5001 \mathrm{~b} / \mathrm{in.}^{2}$ is needed. Room-temperature vulcanized (RTV) silicones typically have a Young's modulus that is about this value, and these predicted results may suggest a partial explanation for solar cell cracking in early-version commercial modules using RTV silicon pottants and aluminum panel substrates. Lastly, the use of a pottant having a Young's modulus of $1000 \mathrm{~b} / \mathrm{in.}{ }^{2}$, such as ethylene vinyl acetate (EVA), would require that the pottant thickness be at least $14 \mathrm{mils}$, and higher-modulus pottants would have to be used in correspondingly higher thicknesses. The dual handicap for aluminum of a high thermal-expansion coefficient and higher material cost as compared to glass, wood, and steel, makes it an unattractive module substrace-panel material.

\section{B. HYGROSCOPIC EXPANSION OF WOOD}

The hygroscopic-expansion coefficient for hardboard is $50 \times 10^{-6}$ in./ in. $/ 1 \%$ relative humidity $(\mathrm{RH})$, compared with its thermal-expansion coefficient of $7.2 \times 10^{-6}$ in./in. $/{ }^{\circ} \mathrm{C}$. These property differences were suspected to be the explanation for a high incidence of fractured solar

THERMAL STRESS ANALYSIS

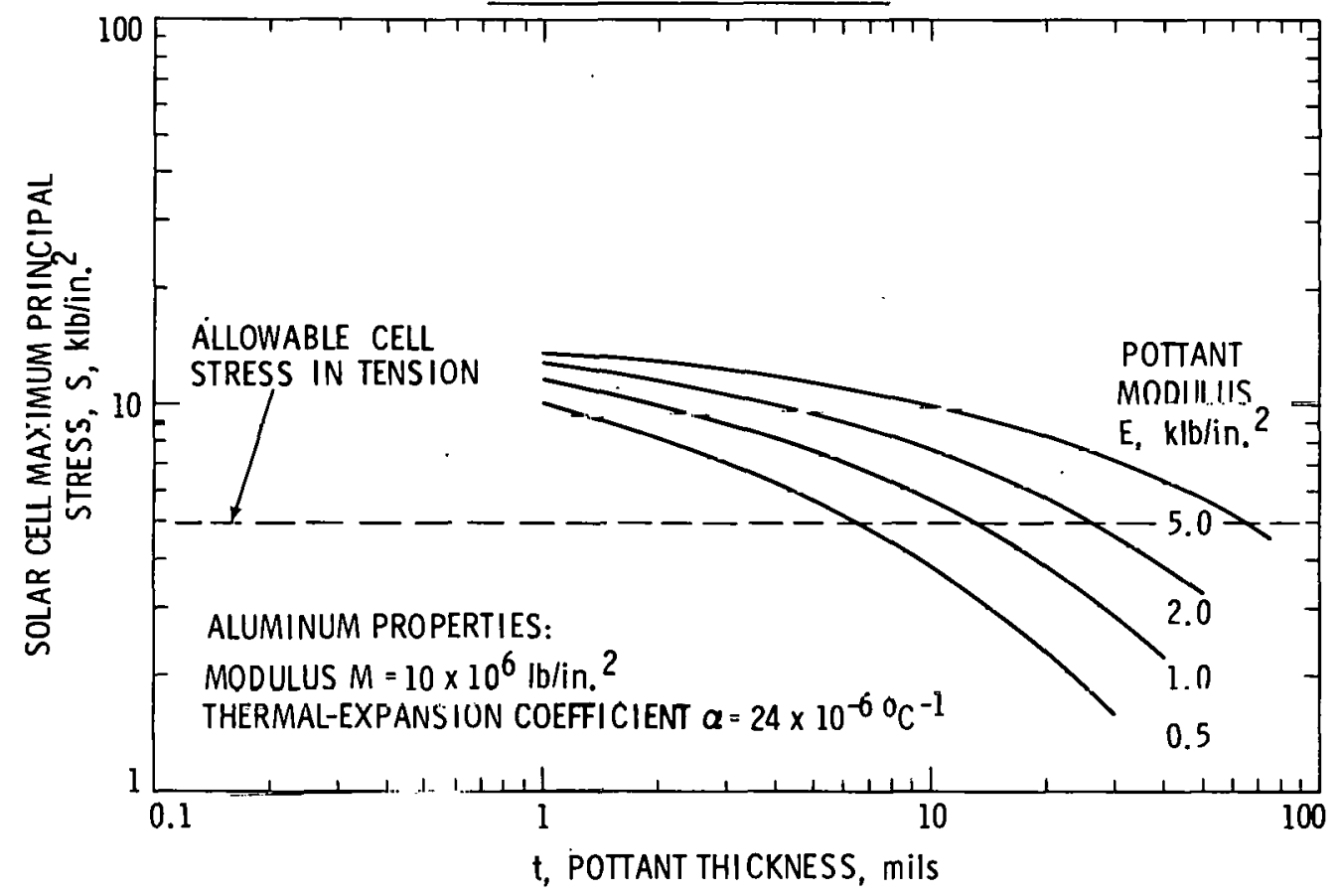

Figure 14. Predicted Stresses of Encapsulated Silicon Solar Cells Using the Figure 13 Master Curve Resulting from Thermal-Expansion Differences in an Aluminum Substrate Module for a $\Delta \mathrm{T}$ of $100^{\circ} \mathrm{C}$ 
cells in experimental EVA-hardboard modules. Investigation determined that during vacuum-bag lamination, unprotected hardboards dry out and shrink, and later, in ambient atmosphere, regain moisture and expand, thereby overstressing the solar cells.

A prediction of the tensile stresses developed in solar cells from the hygroscopic expansion of wood can be generated from the master curve by using the hygroscopic-expansion coefficient and $100 \% \mathrm{RH}$ in place of $100^{\circ} \mathrm{C}$. This is equivalent to considering that the wood panel has a thermal-expansion coefficient $\alpha$ of $50 * 10^{-6}{ }^{\circ} \mathrm{C}^{-1}$.

The predicted $\log -\log$ traces for three levels of Young's modulus of the pottant $\left(E=500,1000\right.$, and $20001 \mathrm{~b} /$ in. ${ }^{2}$ ) are plotted in Figure 15 for a relative-humidity excursion of $100 \%$ (i.e., dry wood to saturated wood).

The predicted solar-cell tensile stresses are enormous, requiring very thick layers of pottant material to damp the generated tensile stresses duwi to acceptable levels. A pottant having a Young's modulus of $500 \mathrm{lb} / \mathrm{in} .{ }^{2}$ would have to be used at a predicted thickness of about $33 \mathrm{mils}$, and a pottant, such as EVA having a Young's modulus of near $1000 \mathrm{lb} / \mathrm{in} .{ }^{2}$, would have to be at least 66 mils thick. Even if the relative-humidity excursion after vacuum-bag lamination were only up to $50 \%$, which is more realistic, the thickness of a pottant, such as EVA, would have to be at least $33 \mathrm{mils}$, which is still very thick compared to practice. The experimental hardboard-modules now fabricated with EVA use no more than $18 \mathrm{mils}$ of EVA between the cells and the wood.

\section{HYGROSCOPIC STRESS ANALYSIS}

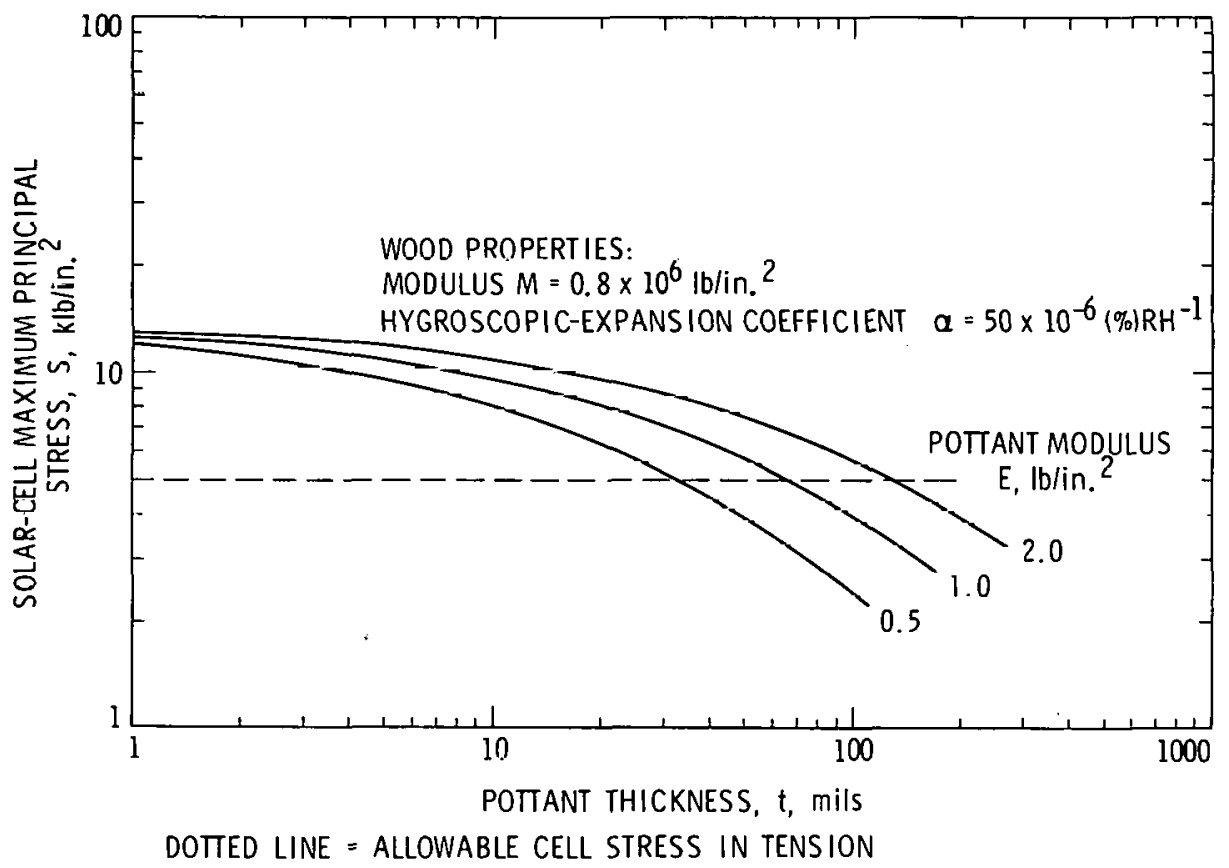

Figure 15. Predicted Stresses in Encapsulated Silicon Solar Cells, Using the Figure 13 Master Curve, Resulting from Hygroscopic Expansion of a Hardboard Pane 1 from $0 \%$ to $100 \%$ Relative Humidity 
The predicted results and actual observations of a high incidence of solar-cell cracking with EVA-hardboard modules fabricated by vacuum-bag lamination are the main thrust behind Encapsulation Task activities to find practical ways to protect wood against drying out during vacuum-bag lamination. 


\section{THIS PAGE \\ WAS INTENTIONALLY \\ LEFT BLANK}


The linear computer traces for deflection analysis (Figures 4, 5, and 6) are replotted $\log -\log$ in Figures 16, 17, and 18 for glass, stee 1 , and wood, respectively. For wood, only the computer trace for the unribbed case is replotted log-log. Trial shifting of all of the $\log -\log$ traces, both horizontally and vertically, revealed that a composite master curve could be generated. However, unlike the computer traces for thermal expansion, it was not possible to establish a set of reduced-variable parameters that achieves mathematical merging of the deflection traces into a composite master curve, but partial clues as to some of the terms in the reduced-variable parameters could be determined.

The three $\log -\log$ traces for glass (Figure 16) could be shifted horizontally into a composite curve using the reduced variable $t / E$, as shown in Figure 19. This behavior paralleled the thermal-stress findings.

For steel (Figure 17), the three log-log traces are associated with solar-cell deflection stresses for three different thicknesses of steel plate, and for a single and constant Young's modulus of the pottant of $1 \mathrm{klb} / \mathrm{in} .{ }^{2}$. The reduced variable $t / E$ is assumed to be valid for the abscissa, and for a value of $E=1 \mathrm{klb} / \mathrm{in}^{2}$, the $\log -\log$ trace is properly positioned horizontally for the reduced variable $t / E$. Vertical merging of these three log-log traces into a composite curve could be achieved as shown in Figure 20 through use of a

\section{DEFLECTION STRESS ANALYSIS}

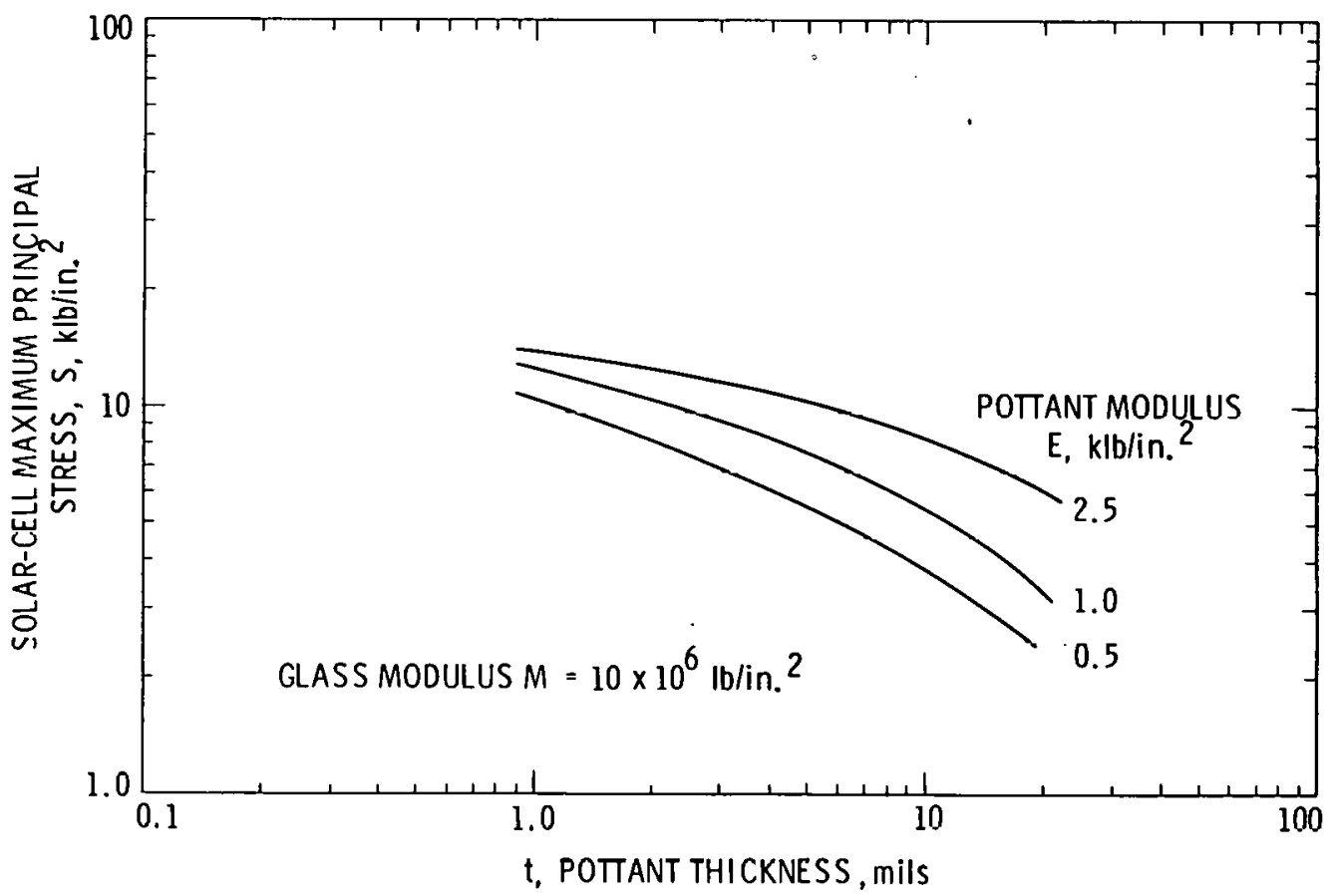

Figure 16. Log-Log Plots of the Computer Traces Given in Figure 4 for the Glass-Superstrate Module 


\section{DEFLECTION STRESS ANALYSIS}

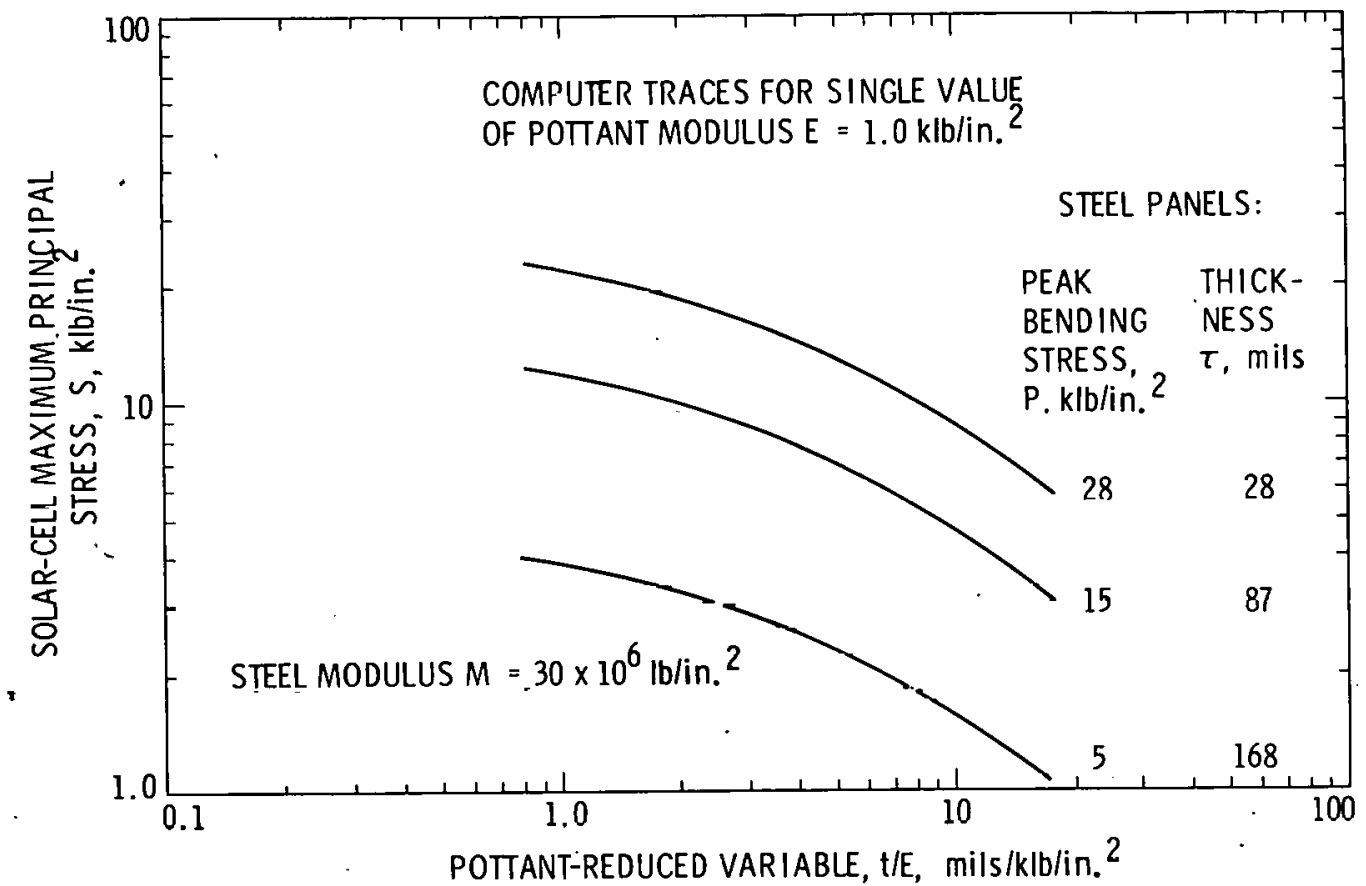

Figure 17. Log-Log Plots of the Computer Traces Given in Figure 5 of a Stee1-Substrate Module

DEFLECTION STRESS ANALYSIS

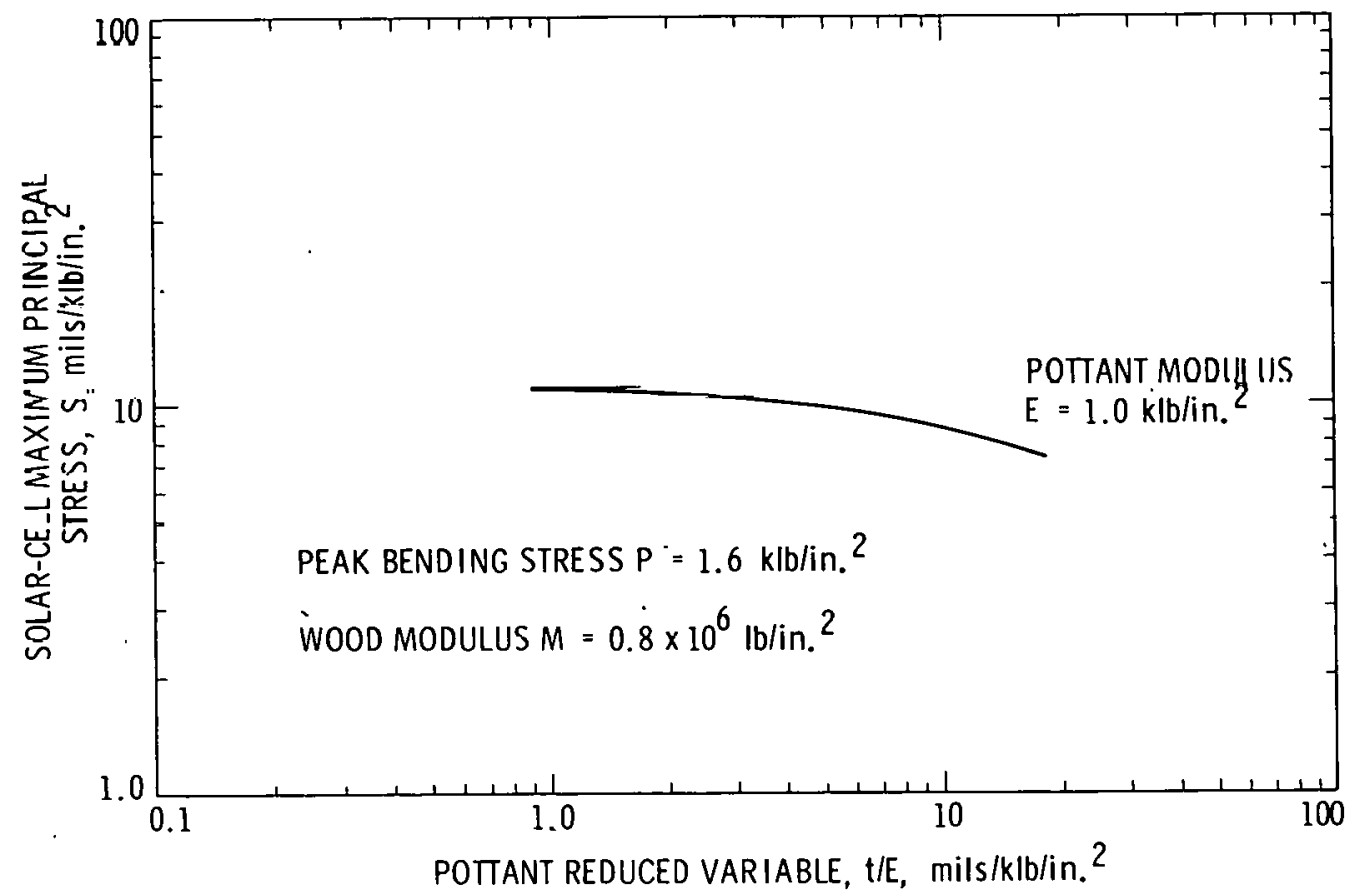

Figure 18. Log-Log Plot of the Computer Trace Given in Figure 6 for the Unribbed Wood-Substrate Module 


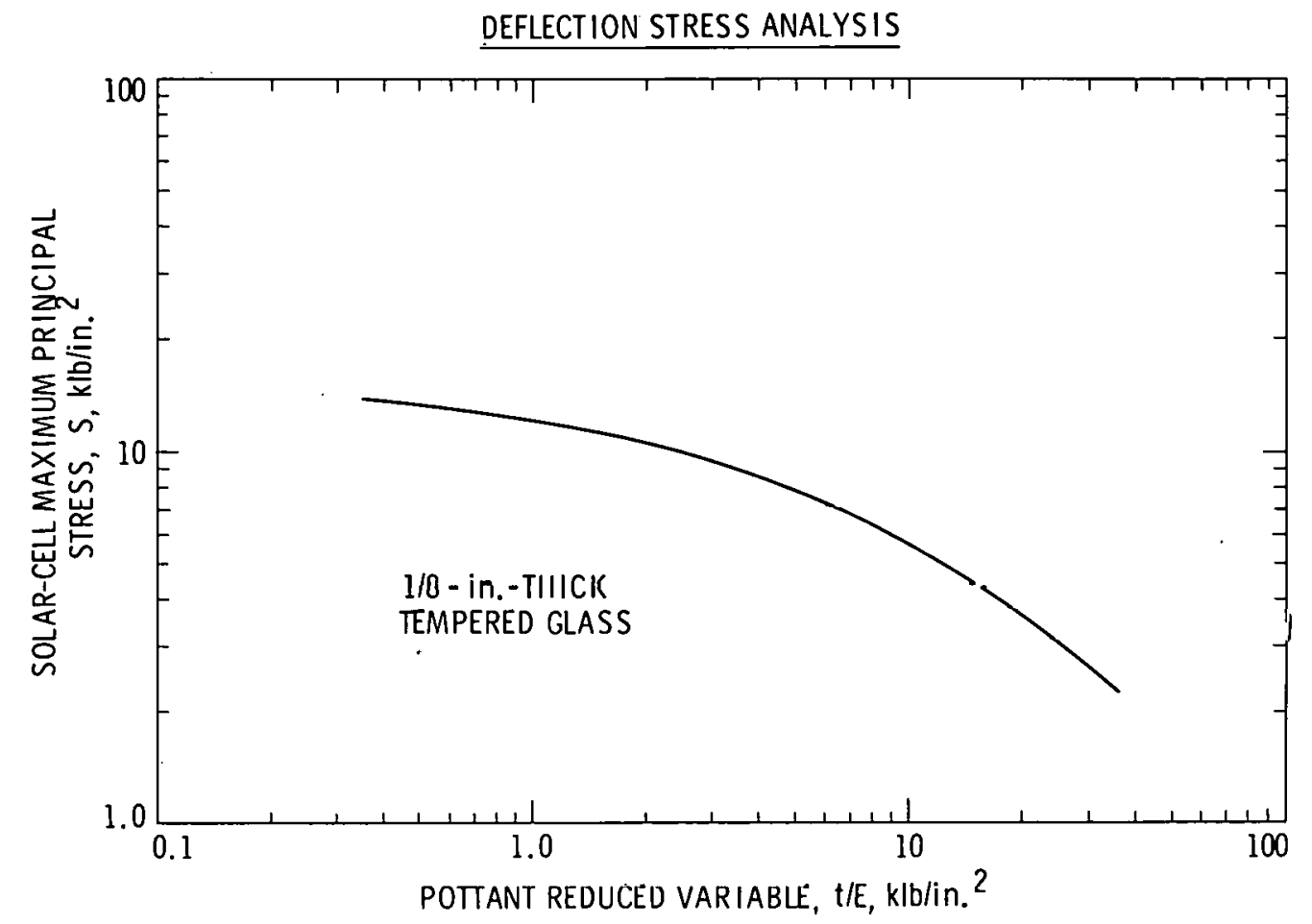

Figure 19. Horizontally Shifted Computer Traces of Figure 16 for Glass Using the Reduced Variable, $t / E$

\section{DEFLECTION STRESS ANALYSIS}

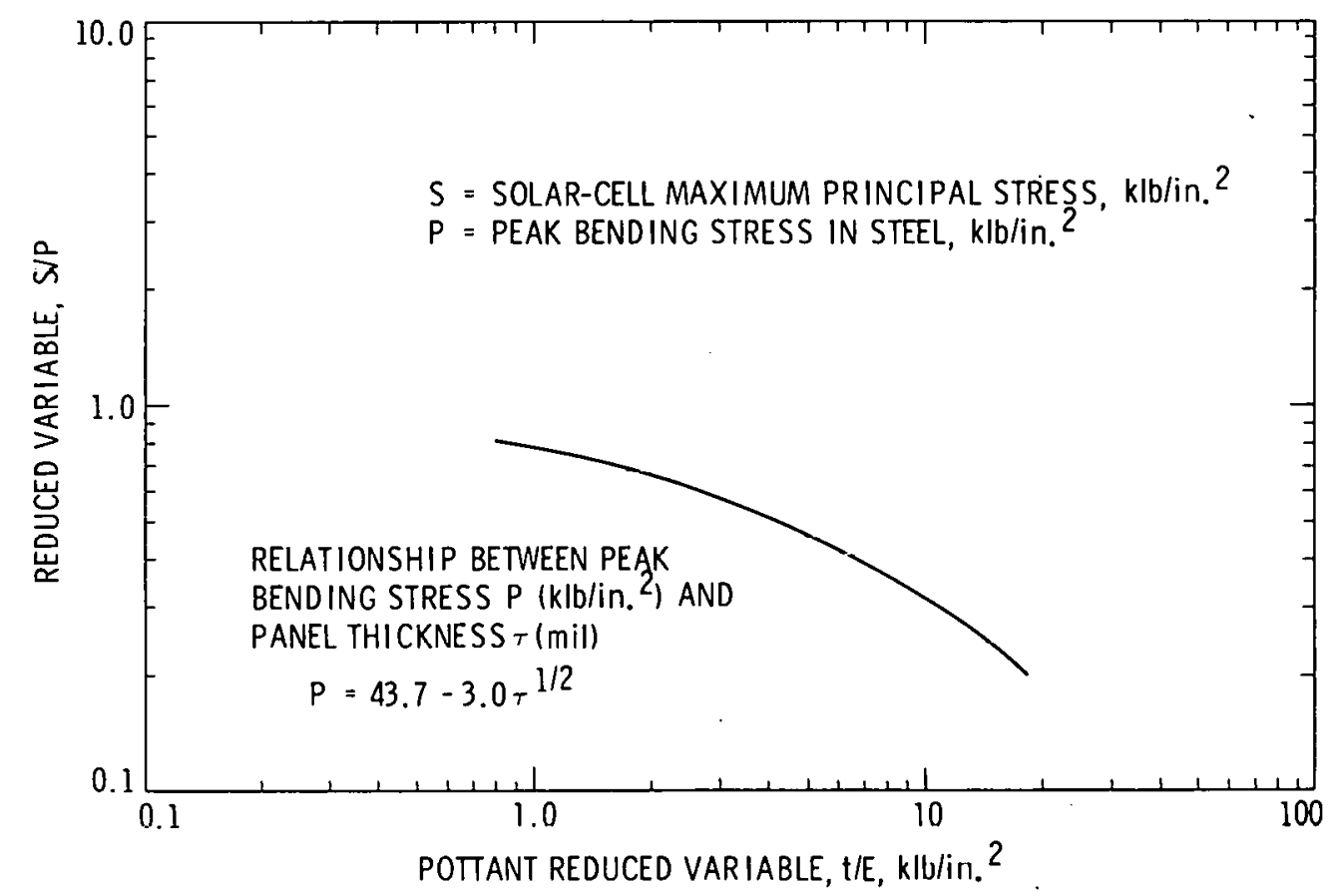

Figure 20. Vertically Shifted Computer Traces of Figure 17 for Steel Using the Reduced Variable $\mathrm{S} / \mathrm{P}$ 
reduced parameter $S / P$, where $S$ is the solar-cell stress in units of $\mathrm{klb} / \mathrm{in} .{ }^{2}$, and $P$ is the peak bending stress of the steel plate, also in units of $\mathrm{klb} / \mathrm{in} .^{2}$. Included in Figure 17 are the plate thicknesses $\tau$ associated with the peak bending stresses. Trial and error resulted in identifying a simple, connective relationship between $P$ and $\tau$, as follows:

$$
P=43.7-3.0 \tau^{1 / 2}
$$

where $P$ is expressed in units of $\mathrm{klb} / \mathrm{in} .^{2}$ and $\tau$ is the plate thickness in mils.

Further efforts to identify trends for the reduced-variable expressions were not rewarding. This was primarily due to a lack of sufficient parametric studies on the computer, and also to an ignorance of key terms and/or combinations of terms for deflection analysis that would be expected in reducedvariable schemes for deflection (e.g., the thermal-stiffness term $M \alpha$ which was used in the thermal-stress master curve).

To illustrate that the three composite traces for wood, glass, and steel (Figures 18, 19, and 20) are segments of a common master curve, the curves were first shifted horizontally (Figure 21), and then vertically to a comnon curve (Figure 22). The individual segments for wood, glass, and steel are marked off in the master curve of Figure 22, so this curve could be used to broaden the $t / E$ scale for each of the three panels. For example, using Figure 20, Figure 22, and Equation (1) for unribbed steel panels, predictions of solar-cel1-bending stresses can be generated for any combinations of pottant modulus and thickness, and thickness of the steel panel.

DEFLECTION STRESS ANALYSIS

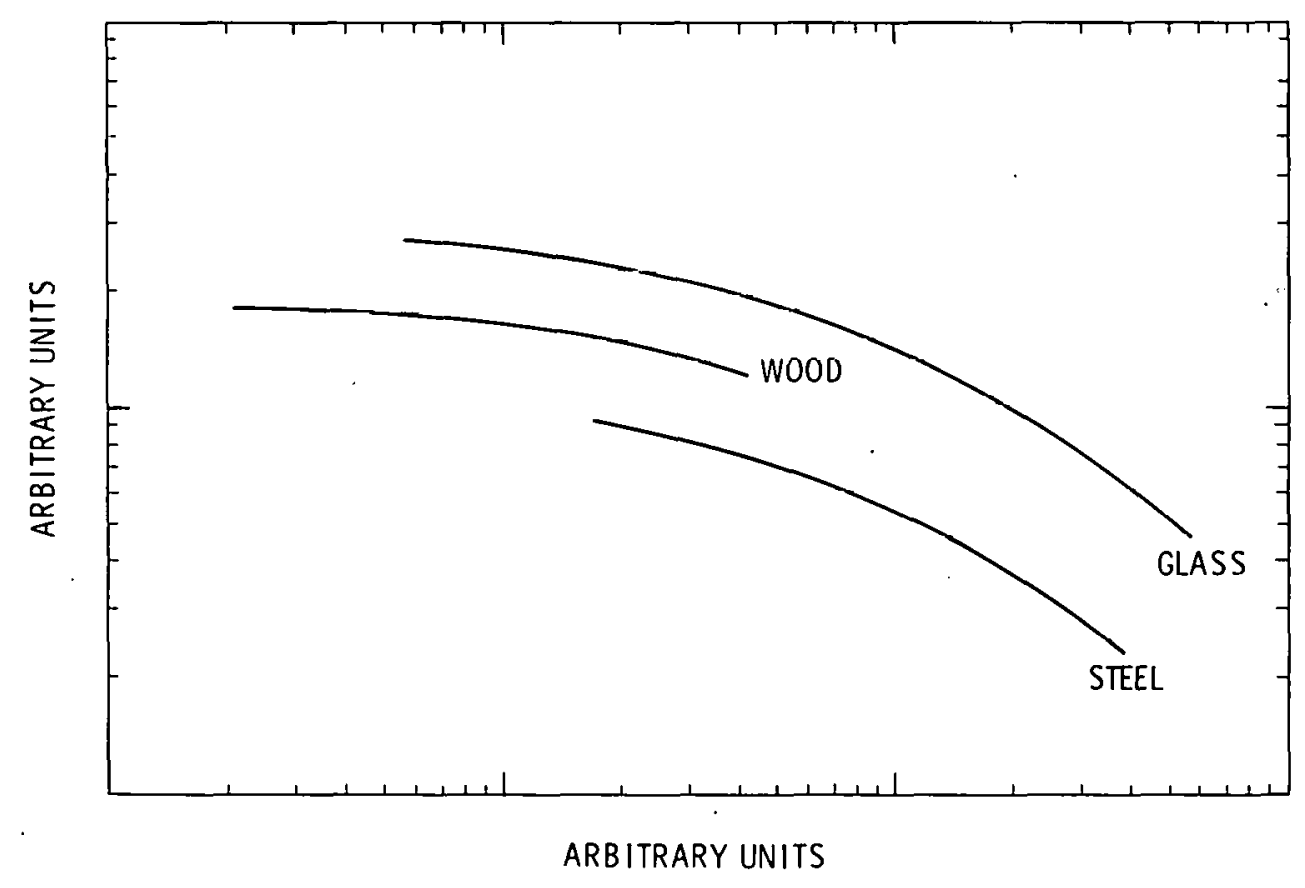

Figure 21. Horizontally Shifted Composite Computer Traces of Figures 18, 19, and 20 for Wood, Glass, and Steel to Demonstrate Potential of Superposition to a Master Curve 


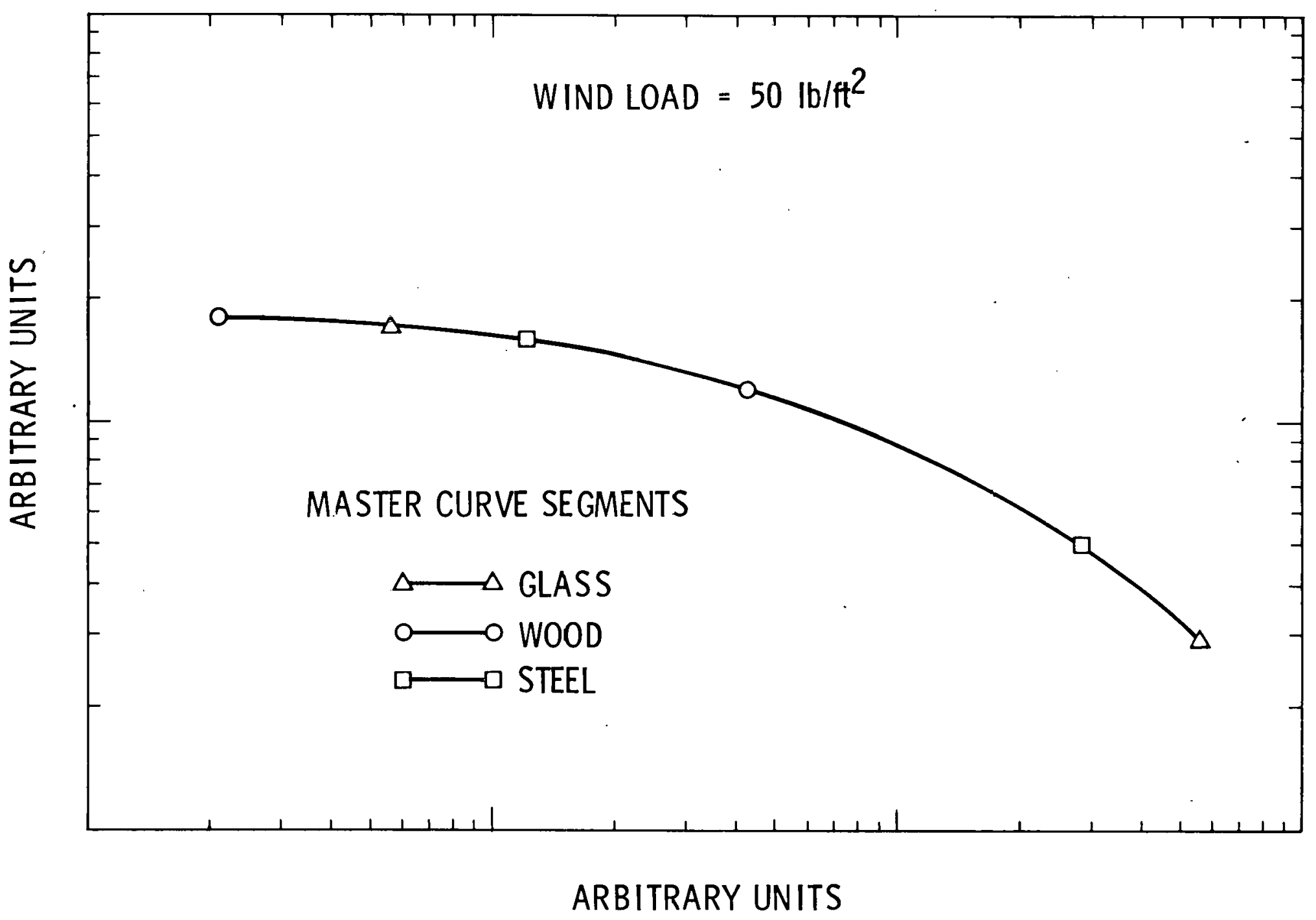

Figure 22. Master Curve for Deflection Stress Analysis 


\section{THIS PAGE \\ WAS INTENTIONALLY \\ LEFT BLANK}




\section{SECTION $\mathrm{V}$}

FUTURE WORK

The concept of generating reduced-variable master curves to enable desktop predictions of stresses developed in encapsulated solar cells that result from thermal expansion and contraction and out-of-plane deflections of modules is an attractive goal. The preliminary efforts described in this report, using computer traces of predicted stresses for a few test cases, indicate that such a goal may be attainable. Expansion of the computer studies at Spectrolab is planned to investigate more fully some of the parameters already studied and to introduce new parameters of technical interest into the computer programs. The parameter studies will be directed preferentially toward master-curve development, and to assess expeditiously the proper placement of the parameters into reduced-variable terms. Table 2 is a general tabulation of parameters being considered for the study.

Table 2. General List of Structural Parameters Considered for Reduced-Variable, Master-Curve Studies

\begin{tabular}{|c|c|c|}
\hline Pottants & Solar Cells & Panels \\
\hline Modulus & Modulus & Modulus \\
\hline Thickness & $\begin{array}{l}\text { Dimensions (thickness, } \\
\text { width, length) }\end{array}$ & $\begin{array}{l}\text { Dimensions (thickness, } \\
\text { width, length) }\end{array}$ \\
\hline $\begin{array}{l}\text { Thermal-expansion } \\
\text { coefficient }\end{array}$ & $\begin{array}{l}\text { Therma1-expansion } \\
\text { coefficient }\end{array}$ & $\begin{array}{l}\text { Thermal-expansion } \\
\text { coefficient }\end{array}$ \\
\hline $\begin{array}{l}\text { Hygroscopic-expansion } \\
\text { coefficient }\end{array}$ & $\begin{array}{l}\text { Intercel1-spacing } \\
\text { geometry (i.e., round, } \\
\text { square, rectangle, etc.) }\end{array}$ & $\begin{array}{l}\text { Hygroscopic-expansion } \\
\text { coefficient }\end{array}$ \\
\hline
\end{tabular}




\section{THIS PAGE \\ WAS INTENTIONALLY \\ LEFT BLANK}


1. Carrol1, W., Cuddihy, E.F., and Salama, M., "Materials and Design Considerations of Encapsulants for Photovoltaic Arrays in Terrestrial Applications," Proceedings of the 12th IEEE Photovoltaic Specialists Conference, November 1976.

2. Chen, C.P., Fracture Strength of Silicon Solar Cells, Publication No. 79-102, Jet Propulsion Laboratory, Pasadena, California, October 15, 1979.

3. Cuddihy, E.F., and Carro11, W.F., "Consideration of Encapsulants for Photovoltaic Arrays in Terrestrial Applications," Proceedings of the 1976 Meeting of the Society of Photo-Optical Instrumentation Engineers, August 1976. 